

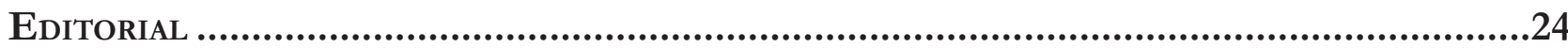

O Direito na fronteira da razão: Psicologia, neurociência e economia comportamental................... 24 Patrícia Perrone Campos Mello e Sergio Nojiri

I. NeURodireito: COGNIÇão, EMOÇÃo, JUÍZOS MORAIS E CIÊNCIA ..........................................26

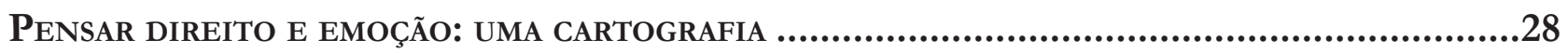

Nevita Maria Pessoa de Aquino Franca Luna

Neurodireito: o início, o fim E O MEIO

Carlos Marden e Leonardo Martins Wykrota

ENSAIO JURÍDICO SOBRE A RACIONALIDADE HUMANA: MAIORES, CAPAZES E IRRACIONAIS

André Perin Schmidt Neto e Eugênio Facchini Neto

DIVERGÊNCIAS DE PRINCÍPIO: ARGUMENTOS JURÍDICOS E MORAIS EM UM CENÁRIO DE DESACORDOS SOCIAIS

André Matos de Almeida Oliveira, Pâmela de Rezende Côrtes e Leonardo Martins Wykrota

CONSILIÊNCIA E A POSSIBILIDADE DO NEURODIREITO: DA DESCONFIANÇA À RECONCILIAÇÃO DISCIPLINAR.....

Thaís de Bessa Gontijo de Oliveira e Renato César Cardoso

MODELOS DE MORALIDADE

Molly J. Crockett

A INFELIZ BUSCA POR FELICIDADE No DiREITo

Úrsula Simões da Costa Cunha Vasconcellost, Noel Struchiner e Ivar Hannikainen

Além da liberdade: PersPeCtivas Em Nietzsche.

Lucas Costa de Oliveira

A mediaÇão de CONFlitos SOb a PERSPECTIVA do DESENVOLVIMENTO HUMANO: AS CONTRIBUIÇÕES DA PSICOLOGIA POSITIVA

Simone de Biazzi Ávila Batista da Silveira e Deise Brião Ferraz

Neuroimagiologia e aValiação de ResPonsabilidade

Nicole A. Vincent 
ANÁLISE CRÍTICA DA ORIENTAÇÃO DE CIDADÃOS COMO MÉTODO PARA OTIMIZAR DECISÕES PÚBLICAS POR MEIO DA TÉCNICA NUDGE.

Luciana Cristina Souza. Karen Tobias França Ramos e Sônia Carolina Romão Viana Perdigão

Políticas públicas e o deVer de monitoramento: “LEVANdo os Direitos A SÉrio". .252 Ana Paula de Barcellos

Nudges E POLÍticas PÚblicas: uM MECANISMO DE COMBATE AO TRABALHO EM CONDIÇÃo ANÁLOGA À DE ESCRAVO .267

Amanda Carolina Souza Silva, Débhora Renata Nunes Rodrigues e Saul Duarte Tibaldi

REDUZINDO A TRIBUTAÇÃO COGNITIVA: LIÇÕES COMPORTAMENTAIS PARA A DIMINUIÇÃO DOS EFEITOS PSICOLÓGICOS ADVERSOS DA POBREZA.............................................................288 Leandro Novais e Silva, Luiz Felipe Drummond Teixeira, Gabriel Salgueiro Soares e Otávio Augusto Andrade Santos

Políticas PÚBLICAS EM SUICÍDIO: DO PATERNALISMO CLÁSSICO AO PATERNALISMO LIBERTÁRIO E NUDGING

Davi de Paiva Costa Tangerino, Gabriel Cabral e Henrique Olive

Nudges COMO POLÍticA PÚbliCA PARA AUMENTAR O ESCASSO NÚMERO DE DOADORES DE ÓRGÃos PARA TRANSPLANTE

Roberta Marina Cioatto e Adriana de Alencar Gomes Pinheiro

Os PROGRAMAS DE INTEGRIDADE PARA CONTRATAÇÃO COM A ADMINISTRAÇÃO PÚBLICA ESTADUAL: NUDGE OU OBRIGAÇÃo LEGAL? UM OLHAR SOBRE AS DUAS PERSPECTIVAS .386

Cíntia Muniz Rebouças de Alencar Araripe e Raquel Cavalcanti Ramos Machado

Paternalismo libertário e Proteção JURídica do AMbiente: POR QUe PROTEger o AMBIENTE TAMBÉM DEVE SER PROTEGER AS LIBERDADES?

Mariana Carvalho Victor Coelho e Patryck de Araujo Ayala

Políticas públicas baseadas EM EVIdÊNCIAS COMPORTAMENTAIS: REFLEXões A PARTIR do Projeto de Lei 488/2017 do Senado

Pâmela de Rezende Côrtes, André Matos de Almeida Oliveira e Fabiano Teodoro de Rezende Lara

III. ECONOMIA COMPORTAMENTAL: VIESES COGNITIVOS E POLÍTICAS PÚBLICAS .455

ECONOMIA COMPORTAMENTAL E DIREITO: A RACIONALIDADE EM MUDANÇA Marcia Carla Pereira Ribeiro e Victor Hugo Domingues

VIESES COGNITIVOS E DESENHO DE POLÍTICAS PÚBLICAS 
A neurociênCia da moralidade na tomada de DeCisões Jurídicas Complexas e No DESENHO DE POLÍTICAS PÚBLICAS

Erik Navarro Wolkart

Desvio de CARÁter ou SIMPLESMENTE HUMANO? ECONOMIA COMPORTAMENTAL APLICADA AO COMPORTAMENTO DESONESTO

Diana Orghian, Gabriel Cabral, André Pinto e Alessandra Fontana

Políticas Públicas e a ConcretizaÇão de direitos sociais: TOMAdA DE DECisão, ARQUITETURA DE ESCOLHAS E EFETIVIDADE

Ana Elizabeth Neirão Reymão e Ricardo dos Santos Caçapietra

BEHAVIORAL ECONOMICS E DIREITO DO CONSUMIDOR: NOVAS PERSPECTIVAS PARA O ENFRENTAMENTO DO SUPERENDIVIDAMENTO .568

Samir Alves Daura

A EDUCAÇÃo FORMAL PARA O CONSUMO É GARANTIA PARA UMA PRESENÇA REFLETIDA DO CONSUMIDOR NO MERCADO? UMA ANÁLISE COM BASE NA BEHAVIORAL LAW AND ECONOMICS (ECONOMIA COMPORTAMENTAL) 600

Marcia Carla Pereira Ribeiro e Edson Mitsuo Tiujo

LIBET, DETERMINISMO E CONSUMO: AS INFLUÊNCIAS DO MARKETING E A RELEVÂNCIA DA DELIBERAÇÃo CONSCIENTE NA SUPERAÇÃo CONDICIONAL DE HÁBITOS DE CONSUMO PERIGOSOS616 Émilien Vilas Boas Reis e Leonardo Cordeiro de Gusmão

CiÊNCIA DO DIREITO TRIBUTÁRIO, ECONOMIA COMPORTAMENTAL E EXTRAFISCALIDADE. .640 Hugo de Brito Machado Segundo

IV. CoMportamento JUdiCiAL: INFLUÊNCIA DE FATORES EXTRAJURÍDicos .660

FATORES METAPROCESSUAIS E SUAS INFLUÊNCIAS PARA A FORMAÇÃo DA DECISÃo JUDICIAL .662 Rogério Roberto Gonçalves de Abreu, Lúcio Grassi de Gouveia e Virgínia Colares

“A VIDA COMO ELA É": COMPORTAMENTO ESTRATÉGICO NAS CORTES Patrícia Perrone Campos Mello

A COMPOSIÇÃo do ÓRGão COLEGIAdo E SEUS EFEITOS NA TOMADA DE DECISÃo .720 André Garcia Leão Reis Valadares

Das 11 ilhas ao centro do arquipélago: os superpoderes do Presidente do STF DURANTE O RECESSO JUDICIAL E FÉRIAS .741 José Mário Wanderley Gomes Neto e Flávia Danielle Santiago Lima 
RAZÃo, EMOÇÃo E DELIBERAÇÃO: AS ADEQUAÇÕES REgIMENTAIS do SUPERIOR TribUNAL DE JUSTIÇA PARA A FORMAÇÃo DE PRECEDENTES EFICAZES

Peter Panutto e Lana Olivi Chaim

Heurística de ancoragem e fiXaÇÃo de danos morais em JUizados especiais Cíveis no Rio DE JANEIRO: UMA NOVA ANÁLISE 778

Fernando Leal e Leandro Molhano Ribeiro

LA PROTECCIÓN DE LOS DERECHOS POLÍTICOS FRENTE A LAS FUNCIONES DISCIPLINARIAS DE LAS AUTORIDADES ADMINISTRATIVAS: SUBSIDIARIEDAD Y DEFERENCIA EN EL SISTEMA INTERAMERICANO DE DERECHOS HUMANOS. Jorge Ernesto Roa Roa

V. A influênCia do gÊNERo no PROCESSO DECisório JUdiCial

Como os Juízes decidem os Casos de estupro? ANALISANDo SENTENÇAS SOb A PERSPECTIVA DE VIESES E ESTEREÓTIPOS DE GÊNERO 826 Gabriela Perissinotto de Almeida e Sérgio Nojiri

GÊNERO E COMPORTAMENTO JUDICIAL NO SUPREMO TRIBUNAL FEDERAL: OS MINISTROS CONFIAM MENOS EM RELATORAS MULHERES?

Juliana Cesario Alvim Gomes, Rafaela Nogueira e Diego Werneck Arguelhes

Hércules, Hermes e a pequena sereia: Uma reflexão sobre estereótipos de gênero, SUbPRESENTAÇÃo DAS MULHERES NOS TRIBUNAIS E (I)LEGITIMIDADE DEMOCRÁTICA DO PODER JUDICIÁRIO .878 Jane Reis Gonçalves Pereira e Renan Medeiros de Oliveira

Prisão Cautelar de gestantes: análise do Fundamento filosófico da decisão do Habeas CoRpus N. 143.641 912

Artur César Souza e Giovania Tatibana de Souza

VI. Neurodireito APlicado ao direito E Ao Processo PENAL....................................926

CÉREbros QUe PUNEM: UMA REVISÃo CRÍTICA DA NEURoCIÊNCIA DA PUNIÇÃo .....................928 Ricardo de Lins e Horta

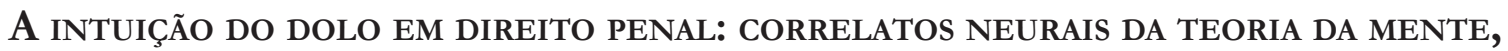
RACIOCÍNIO INDUTIVO E A GARANTIA DA CONVICÇÃO JUSTIFICADA. .946 Thiago Dias de Matos Diniz e Renato César Cardoso

As COMUNIDADES EPISTÊMICAS PENAIS E A PRODUÇÃo LEGISLATIVA EM MATÉRIA CRIMINAL..... 961 Stéphane Enguéléguélé 
DELINQUÊNCIA JUVENIL: RELAÇÕES ENTRE DESENVOLVIMENTO, FUNÇÕES EXECUTIVAS E COMPORTAMENTO SOCIAL NA ADOLESCÊNCIA

André Vilela Komatsu, Rafaelle CS Costa e Marina Rezende Bazon

Límites TEMPORALES A LAS PENAS PRIVATIVAS DE LIBERTAD ATENDIENDO AL DESARROLLO PSICOSOCIAL.

Silvio Cuneo Nash

NEURolaw E AS PERSPECTIVAS PARA UMA ANÁLISE OBJETIVA DO COMPORTAMENTO SUGESTIONADO: REPERCUSSÃO DAS FALSAS MEMÓRIAS NA ESFERA PENAL

Mariana Dionísio de Andrade, Marina Andrade Cartaxo e Rafael Gonçalves Mota

A falibilidade da memória nos Relatos testemunhais: implicaÇões das falsas Memórias NO CONTEXTO DOS CRIMES CONTRA A DIGNIDADE SEXUAL 1036

Caroline Navas Viana

A (IR)REPETIBILIDADE dA PROVA PENAL DEPENDENTE DA MEMÓRIA: UMA DisCUSSÃo COM BASE NA PSICOLOGIA DO TESTEMUNHO. 1058

William Weber Cecconello, Gustavo Noronha de Avila e Lilian Milnitsky Stein 


\section{Hércules, Hermes e a pequena sereia: Uma reflexão sobre estereótipos de gênero, subpresentação das mulheres nos tribunais e (i) legitimidade democrática do Poder Judiciário*}

\section{Hércules, Hermes and The Little Mermaid: \\ a reflection on gender stereotypes, women subpresentation in the courts and the democratic (i)legitimacy of the judiciary}

Jane Reis Gonçalves Pereira**

Renan Medeiros de Oliveira***

\begin{abstract}
"Once we accept that who the judge is matters, then it matters who our judges are".

Erica Rackley ${ }^{1}$
\end{abstract}

\section{Resumo}

O presente artigo tem por objetivo explorar as correlações entre os estereótipos de gênero, déficits de representatividade feminina nas cúpulas do poder judiciário e o debate sobre a (i)legitimidade democrática desse ramo de poder. Em primeiro lugar, apresentamos a divisão público-privado na teoria feminista e analisamos os arquétipos do juiz ideal na teoria jurídica. Para isso, recorremos à metodologia da revisão bibliográfica. Em sequência, fazemos um levantamento de dados sobre a composição dos órgãos de cúpula do poder judiciário, com foco nos tribunais superiores e na justiça federal, que demonstram baixa representatividade de gênero e indicam uma tendência à estratificação na composição desses setores. Por fim, com base na análise dos dados, desenvolvemos a tese prescritiva de que o incremento da diversidade na composição da magistratura é um requisito para a afirmação da sua legitimidade democrática. Em conclusão, formulamos uma defesa não essencialista do equilíbrio de gênero na composição dos órgãos do judiciário, escorada na premissa de que a diversidade nos órgãos estatais é uma exigência do princípio democrático. A conexão entre representatividade como pressuposto da legitimidade democrática do judiciário é um tópico ainda pouco explorado, que ganha relevância no contexto em que se dissemina a ideia de que as cortes constitucionais têm papel representativo.

Palavras-Chave: Diversidade de gênero. Poder Judiciário. Legitimidade Democrática. no Centro de Justiça e Sociedade da Fundação Getulio Vargas (CJUS/FGV) e na Clínica de Direitos Fundamentais da Faculdade de Direito da UERJ - Clínica UERJ Direitos. Pesquisador Permanente do Laboratório de Regulação Econômica da UERJ - UERJ Reg.

E-mail: renanmedeirosdeoliveira@gmail.com
1 RACKLEY, Erika. Women, judging and the Judiciary: from difference to diversity. New York: Routledge, 2013. p. 164. 
The purpose of this article is to explore the correlations between gender stereotypes, deficits of female representation in the judiciary, and the debate about the democratic (i)legitimacy of this branch of power. First, we present the public-private division in feminist theory and analyze the archetypes of the ideal judge in legal theory. For this, we resorted to the methodology of the bibliographic review. In the sequence, we collect data on the composition of the highest-level organs of the judiciary, focusing on the higher courts and federal courts, which show a low gender representation and indicate a tendency to stratification in the composition of these sectors. Finally, based on the analysis of the data, we develop the prescriptive thesis that increasing the diversity in the composition of the judiciary is a requirement for affirming the democratic legitimacy of the judiciary. In conclusion, we formulate a non-essentialist defense of gender balance in the composition of the organs of the judiciary, based on the premise that diversity in state organs is a requirement of the democratic principle. The connection between representativeness as a presupposition of the democratic legitimacy of the judiciary is a topic still little explored, which gains relevance in the context in which the idea that the constitutional courts would have a representative role is disseminated.

Keywords: Gender diversity. Judicial power. Democratic legitimacy.

\section{INTRODUÇÃo}

Os alicerces básicos das democracias liberais foram desenhados quando as mulheres praticamente não participavam dos processos deliberativos do Estado. Essa conjuntura histórica ainda repercute no cotidiano, mas nem sempre é simples notar como a dinâmica dos espaços de decisão espelha uma assimetria ancestral de poder entre homens e mulheres.

A esfera pública estatal costuma ser idealizada como neutra em relação ao gênero ${ }^{2}$. As discussões sobre a estrutura do estado constitucional - imaginada como imparcial e objetiva - raramente levam em conta o fato de que sua configuração foi traçada em um contexto de distribuição desigual dos papeis dos homens e das mulheres nos espaços públicos e privados. Na prática jurídica, não é comum debater de que forma os estereótipos de gênero condicionam a arquitetura institucional dos órgãos do Estado. A apreciação e crítica dessa dinâmica está insulada nos estudos feministas, permanecendo negligenciada pela teoria política e constitucional hegemônica.

Exemplos caricatos ilustram como o ethos $^{3}$ dos órgãos do estado é impregnado de vieses masculinos. Até o ano 2000, era proibida a entrada de mulheres vestindo calças no plenário do Supremo, sendo que apenas em 2007 esse traje foi usado por uma ministra pela primeira vez ${ }^{4}$. Somente em 2016 o plenário do Senado em Brasília, inaugurado em 1960, passou a ter um banheiro para as senadoras ${ }^{5}$. Nas sabatinas que precedem

2 No presente estudo, adotamos o sentido de gênero empregado por SCOTT, Joan. Gênero: uma categoria útil de análise histórica. Educação \& Realidade, Porto Alegre, v. 20, n. 2, p. 71-99, jul./dez. 1995.

3 Sobre o conceito de ethos, cf. BOURDIEU, Pierre. The logic of practice. Cambridge: Polity Press, 1990. BOURDIEU, Pierre. Esboço de uma teoria da prática: precedido de três estudos de etnologia kabila. Oeiras: Celta, 2002. BOURDIEU, Pierre. Distinction: a social critique of the judgment of taste. Cambridge: Harvard University Press, 1984. AMOSSY, Ruth (Org.). Imagens de si no discurso: a construção do ethos. São Paulo: Contexto, 2005. WACQUANT, Loïc. Esclarecer o habitus. Educação \& Linguagem, ano 10, n. 16, p. 63-71, jul./dez. 2007.

4 D’ELLA, Mirella. Ministra quebra tradição e usa calça no STF. Brasília. 2007. Disponível em: <http://g1.globo.com/Noticias/ Politica/0,MUL11565-5601,00-MINISTRA+QUEBRA+TRADICAO+E+USA+CALCA+NO+STF.html>. Acesso em: 27 maio 2018.

5 ALEGRETTI, Laís. Plenário do Senado terá banheiro feminino 55 anos após inauguração. Brasília. 2016. Disponível em: < http:// g1.globo.com/politica/noticia/2016/01/plenario-do-senado-tera-banheiro-feminino-55-anos-apos-inauguracao.html>. Acesso em: 27 maio 2018. 
as nomeações ao STF, as ministras depararam-se com perguntas constrangedoras que abordam sua beleza e "elegância física”.

A resistência à inserção das mulheres nos espaços de poder, porém, vai muito além da alteração de códigos de vestimenta, das reformas arquitetônicas e da etiqueta no tratamento em contextos profissionais. $\mathrm{O}$ poder judiciário, especialmente nos estratos mais elevados, é um ambiente particularmente refratário à discussão sobre diversidade de gênero. Não raro, a questão é minimizada sob o argumento de que a paridade na composição dos tribunais surgirá como um efeito natural da inserção das mulheres no mercado de trabalho. Nesse cenário, as recentes iniciativas no sentido de apurar e monitorar dados sobre a disparidade entre homens e mulheres abrem um campo importante de reflexão sobre o tema?

O presente artigo tem por objetivo analisar as relações entre a dicotomia público-privado, os estereótipos relacionados à figura do juiz ideal, a baixa representação feminina em tribunais e as implicações dessa configuração para a legitimação democrática do judiciário.

Quanto ao recorte do objeto de estudo, é importante fazer uma advertência inicial. Assumimos que a noção de diversidade na magistratura e suas implicações para as demandas de inclusão e legitimação democrática envolve mais que gênero ${ }^{8}$, abarcando também questões como raça, orientação sexual, origem social e até mesmo background profissional. Todavia, o presente artigo focará apenas a disparidade de gênero no judiciário, sem que isso signifique pressupor que esse aspecto é único ou preponderante nos debates sobre diversidade e democracia.

As questões de gênero e suas relações com a magistratura têm ganhado destaque na produção acadêmica nacional e internacional. Todavia, a conexão entre representatividade de gênero como pressuposto da legitimidade democrática do judiciário é um tópico ainda pouco explorado, que ganha relevância no contexto em que se dissemina a ideia de que as cortes constitucionais desempenham um papel representativo.

O estudo está dividido em três blocos. Na primeira parte, a dinâmica de gênero no poder judiciário é analisada a partir de dois referenciais teóricos. De um lado, abordamos a produção filosófica feminista que indica como a dicotomia público versus privado é generificada. Em sequência, avaliamos como, na filosofia do direito, a discussão sobre o juiz ideal é povoada por arquétipos mitológicos masculinos. O objetivo, nesse ponto, não é explorar quais são os melhores modelos de juiz, mas demonstrar como o repertório simbólico

6 ARAUJO, Heloisa Bianquini. Qual o gênero do Supremo?: diálogo institucional nas sabatinas para o STF, poder e profissionalismo. 2015. Trabalho de Conclusão de Curso (Graduação em Direito) - Escola de Formação da Sociedade Brasileira de Direito Público, São Paulo, 2015. p. 62.

7 COMISSÃO AJUFE MULHERES. Nota Técnica: AJUFE mulheres 01/2017: resultados da pesquisa para se conhecer o perfil das associadas da AJUFE. Brasília: AJUFE Mulheres, 2017. FRAGALE FILHO, Roberto; MOREIRA, Rafaela Selem; SCIAMMARELLA, Ana Paula de O. Magistratura e gênero: um olhar sobre as mulheres nas cúpulas do judiciário brasileiro. E-cadernos CES, n. 24, p. 57-77, 2015. BONELLI, Maria da Glória. Profissionalismo, gênero e significados da diferença entre juízes e juízas estaduais e federais. Contemporânea, n. 1, p. 103-123, jan./jun. 2011.

8 O feminismo interseccional surgiu a partir do feminismo negro e foi tratado, inicialmente, por Kimberlé Williams Crenshaw, que pontuou que as leis tratavam raça e gênero de formas distintas e nunca interconectadas. Cf. CRENSHAW, Kimberlé Williams; CHO, Sumi; MCCALL, Lesli. Mapping the margins: intersectionality, identity politics, and violence against women of color. Stanford Law Review, v. 43, n. 6, p. 1241-1299, 1991; CRENSHAW, Kimberlé Williams; CHO, Sumi; MCCALL, Lesli. Demarginalizing the intersection of race and sex: a black feminist critique of antidiscrimination doctrine, feminist theory and antiracist politics. The University of Chicago Legal Forum, v. 139, p. 139-167, 1989; CRENSHAW, Kimberlé Williams; CHO, Sumi; MCCALL, Lesli. Toward a field of intersectionality studies: theory, applications, and praxis. Signs: Journal of Women in Culture and Society, v. 38, n. 4, p. 785-810, 2013. bell hooks também contribuiu para o avanço dos estudos sobre interseccionalidade, analisando gênero, raça e classe social. Cf. HOOKS, Bell. Ain't i a woman: black women and feminism. Boston: South End Press, 1981. HOOKS, Bell. Teaching to transgress: education as the practice of Freedom. New York: Routledge, 1994. HOOKS, Bell. Feminism is for everybody: passionate politics. London: Pluto Press, 2000. O feminismo interseccional vem ganhando cada vez mais adeptos, que destacam aspectos importantes que devem ser considerados quando da análise de discriminações e de vulnerabilidades, como orientação sexual. Também há grupos com menor visibilidade, como de feministas mães, de minorias religiosas, dentre outros. Veja-se sobre o tema, ainda: DAVIS, Angela. Mulheres, raça e classe. São Paulo: Boitempo, 2016. HIRATA, Helena. Gênero, classe e raça: interseccionalidade e consubstancialidade das relações sociais. Tempo Social, São Paulo, v. 26, n. 1, p. 61-73, 2014. BRAH, Avtar. Diferença, diversidade e diferenciação. Cardenos Pagu, Campinas, v. 26, p. 329-376, jan./jun. 2006. 
que descreve a figura modelar do bom juiz é marcado por formas masculinas. Na segunda parte, examinamos, descritivamente, como as mulheres estão sub-representadas nas cúpulas do Poder Judiciário, bem como analisamos a aparente tendência à estratificação, uma vez que o aumento na composição nos tribunais superiores não acompanha, proporcionalmente, a inclusão das mulheres nas carreiras jurídicas. Na terceira parte, formulamos a tese de que o incremento da diversidade de gênero no Judiciário é um pressuposto da sua legitimidade democrática e uma exigência para que se possa reconhecer que esse ramo de poder tem uma faceta representativa.

Para os fins buscados no presente artigo, nos valemos, na primeira parte, da revisão bibliográfica sobre a dicotomia público e privado na teoria feminista e o tratamento do juiz ideal na filosofia jurídica. No segundo item, expomos levantamentos de dados colhidos dos sites dos tribunais superiores e de pesquisas recentes, com foco na justiça federal, para expor a baixa representatividade feminina na cúpula do judiciário brasileiro. A partir disto, expomos, na terceira parte, a tese prescritiva de que esse ramo de poder, para aumentar sua legitimidade democrática, deve passar por um incremento da pluralidade na composição de seus órgãos.

Antes de prosseguir, é necessário fazer outro registro quanto ao objeto de análise. Neste estudo, perfilhamos a tese de que a baixa representatividade de gênero no poder judiciário representa um déficit de legitimidade democrática. Contudo, não apresentamos propostas para contornar a baixa presença de mulheres no judiciário. Formulações sobre esse tema são necessárias, mas se enquadrariam em outro campo de investigação.

\section{A DICOTOMIA PÚBLICO-PRIVADO E OS ESTEREÓtIPOS DE GÊNERO NA CONSTRUÇÃO DO JUIZ IDEAL}

\subsection{A dicotomia público-privado na teoria feminista}

Quando se pensa sobre a dicotomia público-privado, costuma-se recorrer à tradição do pensamento liberal como ponto de partida. De acordo com a narrativa típica dessa vertente teórica ${ }^{9}$, a referida divisão desempenharia a função de descrever as duas esferas onde as atividades humanas se desenvolvem, que se distinguem por serem governadas por valores distintos. A primeira representaria a dimensão do exercício da cidadania, sendo o locus por excelência de debate sobre questões de justiça. Já a segunda permaneceria inteiramente apolítica, caracterizando-se como um espaço de autonomia individual, em que a personalidade humana encontraria espaço para florescer. A não intervenção do Estado nessa segunda esfera seria uma premissa para realizar os valores centrais do liberalismo. Na imagem usualmente evocada, as dimensões podem ser representadas por um jardim e por uma praça ${ }^{10}{ }^{11}$.

A teoria feminista tem como um de seus aspectos fundamentais voltar-se contra a construção dessa divisão e as consequências que dela decorrem ${ }^{12}$. Como pontua Seyla Benhabib ${ }^{13}$, desde a origem da família burguesa, apresentava-se uma tensão decorrente da circunstância de que a família era regida pela lógica da

9 É importante destacar que tratar do liberalismo como uma corrente unívoca é uma simplificação, uma vez que há diversas vertentes dessa corrente de pensamento. No presente estudo, tratamos de concepções que colocam a autonomia como valor central. 10 SALDANHA, Nelson. O jardim e a praça: ensaio sobre o lado privado e o lado público da vida social e histórica. Porto Alegre: Sergio Antonio Fabris Editor, 1986.

11 Note que John Stuart Mill, um dos pais do liberalismo, já criticava, no século XVIII, a sujeição da mulher. Cf. MILL, John Stuart. The subjection of women. Indianapolis: Hackett Publishing Company, 1988.

12 Na sempre lembrada afirmação de Carole Pateman, a dicotomia público-privado é, em última análise, o tema central do feminismo. PATEMAN, Carole. The sexual contract. Stanford: Stanford University Press, 1988. p. 11-12.

13 BENHABIB, Seyla. Situating the self: gender, community and postmodernity in contemporary ethics. Cambridge: Polity, 1992. p. 109. 
subordinação à autoridade patriarcal, enquanto, na esfera pública, buscava-se a afirmação de ideias como consentimento, igualdade e liberdades religiosa e econômica. Essa contradição reforçava-se pela retórica de não intrusão na esfera íntima e de que preocupações com justiça seriam estranhas à esfera privada, regida pelo ideal de busca da vida boa.

Conquanto guiada pelo propósito liberal de preservar espaços de escolhas individuais, a divisão público- privado acaba por desconsiderar quais indivíduos têm sua liberdade de escolha protegida, negligenciando a reflexão sobre se algumas pessoas teriam sua autonomia esvaziada no domínio privado. Se um dos postulados máximos do liberalismo é o primado do indivíduo sobre estruturas coletivas (dentre as quais pode-se incluir a família $\left.{ }^{14}\right)$, como explicar a omissão da teoria liberal em questionar se a esfera doméstica - tal como estruturada pelo casamento e demais institutos de um dado ordenamento jurídico - impede o exercício da autonomia pelas mulheres? Conforme aponta Martha Nussbaum, embora construída a partir da noção de centralidade do indivíduo, a teoria liberal é contraditoriamente negligente quanto ao exame da incidência desse valor à mulher ${ }^{15}$.

Um exemplo eloquente dessa incongruência é a descrição fornecida por John Rawls em sua Teoria da Justiça a respeito da família. Ele afirma que a família, em sua concepção ideal e, frequentemente, também na prática, constitui um espaço de altruísmo, em que o agir de seus membros é norteado não pela busca da maximização de vantagens individuais, mas pelo desejo de obter ganhos apenas se estes forem passíveis de beneficiar os demais familiares ${ }^{16}$.

A caracterização da família feita por Rawls é desconcertante por diversos fatores, o primeiro deles a sua dissonância com a realidade. Relatório da ONU de 2015 expôs que 1/3 das mulheres no mundo já sofreu violência física ou sexual de seus parceiros e que, de todos os casos de homicídios perpetrados no contexto familiar, $2 / 3$ tiveram mulheres como vítimas ${ }^{17}$. Longe de um jardim idílico onde suas potencialidades humanas seriam cultivadas, a experiência da mulher no âmbito privado muitas vezes mais se aproxima de uma selva.

Do ponto de vista da divisão e do acesso ao trabalho, o mesmo relatório das Nações Unidas apontou que mulheres habitantes de países em desenvolvimento trabalham, em média, três horas a mais por dia do que homens em atividades não remuneradas e duas horas a mais em países desenvolvidos. No mercado de trabalho, mulheres estatisticamente recebem entre $70 \%$ a $90 \%$ do que homens que trabalham no mesmo setor e durante o mesmo expediente. Outros dados apresentados são os de que o ensino superior traz maior retorno financeiro aos homens do que às mulheres e que estas têm maior probabilidade de buscar trabalhos com jornada de trabalho reduzida ${ }^{18}$.

O modelo de Rawls ilustra como há uma confusão entre os planos descritivo e normativo ao se analisar a dicotomia público-privado. Nesse sentido, uma caracterização factual idealizada e irrealista da esfera privada repercute nas considerações sobre como deve ser tratada. Pode-se cogitar, ainda, que a ambiguidade opere no sentido invertido: buscando legitimar um modelo normativo não intervencionista, ao qual se adere $a$ priori, constrói-se um relato da vida privada que torne essa concepção normativa mais atraente, quando não uma exigência de justiça.

14 Sobre o tema da teoria da justiça e da família, veja-se DUARTE, Cláudia Türner Pereira. O sistema familiar na teoria política: repensando o lugar da criança na teoria da justiça. 2016. Dissertação (Mestrado em Direito) - Universidade do Estado do Rio de Janeiro, Rio de Janeiro, 2016.

15 NUSSBAUM, Martha C. Sex \& social justice. Oxford: Oxford University Press, 1999.

16 RAWLS, John. A theory of justice. Cambridge: Harvard University Press, 2003. p. 90.

17 UNITED NATIONS. The world's women 2015. 2015. Disponível em: < https://unstats.un.org/unsd/gender/chapter4/chapter4.html>. Acesso em: 10 maio 2018.

18 UNITED NATIONS. The world's women 2015. 2015. Disponível em: < https://unstats.un.org/unsd/gender/chapter4/chapter4.html>. Acesso em: 10 maio 2018. 
Tudo isso resulta na frustração de qualquer possibilidade de igualdade de oportunidades. Susan Okin ${ }^{19}$, em sua crítica à forma como a teoria da justiça liberal trata a esfera doméstica, pondera que o casamento é injusto, pois há uma assimetria na capacidade de se deixar a relação, alimentada por uma alocação desigual do trabalho remunerado e não remunerado entre os membros do casal, que ocorre de maneira quase automática, em função do gênero e pela expectativa, que incide muito mais intensamente sobre a mulher, de que terá de conciliar uma eventual carreira com a criação dos filhos. Essa configuração é incompatível com os

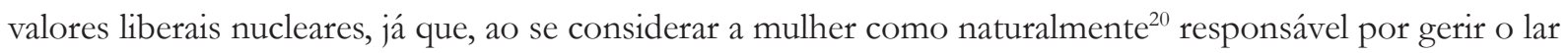
e criar filhos, ela é reduzida à condição de meio para o atingimento de fins alheios, como se a sua dimensão mais elementar fosse a de ser parte da família, e não a de indivíduo autônomo ${ }^{21}$.

O espaço doméstico, como domínio propenso ao exercício de poder e à cristalização de desequilíbrios, com a consequente limitação das opções de quem na sua dinâmica está em situação de desvantagem, não deve ser enxergado como alheio ao espaço público. Nesse sentido é a síntese do célebre slogan feminista: 0 pessoalé político ${ }^{22}$. Esse mote não significa que o público e o privado são (ou devam ser) indistintos, mas que a decisão sobre o que é inserido ou excluído da arena da deliberação público-estatal é inescapavelmente política $^{23}$. Isso altera a forma como se enxergam os contornos do domínio público e do privado, enfraquecendo a visão de que os contornos da vida doméstica seriam naturais, como que um resquício pré-político ${ }^{24}$.

Longe de serem estanques, as duas esferas são permeáveis a influências recíprocas. Público e privado são interdependentes. Por um lado, temas outrora tidos como puramente privados merecem ser tratados como problemas de justiça, pois são pressupostos para garantir um grau de autonomia às pessoas que qualquer versão coerente da teoria liberal entenderia como fundamental ${ }^{25}$. Por outro lado, os espaços públicos estatais também não podem ser encarados como imunes à separação de papéis de gênero que a clássica dicotomia pressupõe. As instituições estatais contemporâneas foram edificadas a partir de uma divisão estereotipada e determinista de tarefas destinadas aos homens e às mulheres, escorada na premissa de que estas se ocupariam das tarefas de cuidado no campo do doméstico, enquanto aos homens competiria ocupar os espaços públicos de poder. Susan Okin formulou com clareza os questionamentos que defluem dessa configuração:

É preciso perguntar: as práticas nos locais de trabalho, no mercado ou no Parlamento seriam as mesmas se elas tivessem se desenvolvido pressupondo que seus participantes teriam de acomodar-se às necessidades de dar à luz, educar um filho, e às responsabilidades da vida doméstica? As políticas e seus resultados seriam os mesmos se aqueles que nelas estão engajados fossem pessoas que também tivessem responsabilidades cotidianas significativas voltadas para os cuidados dos outros, ao invés de

19 OKIN, Susan Moller. Justice, gender and the family. New York: Basic Books, 1989.

20 Parte da teoria feminista dedica-se, com razão, à desconstrução de visões essencialistas, que atribuem como dados naturais e fixos do gênero feminino, atributos socialmente construídos e variáveis. Além de confundir aspectos biológicos com questões sociais, o essencialismo tende a ser excludente, já que dificilmente todas as mulheres se enquadrarão no que é considerado como inerente ao gênero feminino. Para um debate sobre essa e outras vertentes do essencialismo, v.: WITT, Charlotte (Coord.). Feminist metaphysics: explorations in the ontology of sex, gender and the self. Londres: Springer, 2011.

21 NUSSBAUM, Martha C. Sex \& social justice. Oxford: Oxford University Press, 1999. p. 11.

22 O slogan é originado dos escritos de Carol Hanisch. Cf. HANISCH, Carol. The personal is political. Disponível em: < http:// www.carolhanisch.org/CHwritings/PIP.html>. Acesso em: 30 maio 2018. Confira-se o que Susan Okin afirma sobre o tema: "That the personal sphere of sexuality, of housework, of child care and family life is political became the underpinning of most feminist thought. Feminists of different political leanings and in a variety of academic disciplines have revealed and analyzed the multiple interconnections between women's domestic roles and their inequality and segregation in the workplace, and between their socialization in gendered families and the psychological aspects of their oppression. We have strongly and persistently challenged the longstanding underlying assumption of almost all political theories: that the sphere of family and personal life is so separate and distinct from the rest of social life that such theories can justifiably assume but ignore it". OKIN, Susan Moller. Justice, gender and the family. New York: Basic Books, 1989. p. 125-126.

23 OKIN, Susan Moller. Justice, gender and the family. New York: Basic Books, 1989. p. 130.

24 Para uma análise aprofundada de como as teorias contratualistas do período liberal enxergavam na submissão da mulher na esfera privada uma continuação de uma natural assimetria entre os sexos, a qual não constituía um problema político, v. PATEMAN, Carole. The sexual contract. Stanford: Stanford University Press, 1988.

25 BENHABIB, Seyla. Situating the self: gender, community and postmodernity in contemporary ethics. Cambridge: Polity, 1992. p. 109. 
serem aqueles que menos probabilidade têm, em toda a sociedade, de ter essa experiência? ${ }^{26}$

Essas perguntas, formuladas há quarenta anos, ainda são decisivas e atuais para a análise crítica da configuração das instituições judiciárias e das implicações práticas e teóricas da baixa diversidade de gênero nos espaços onde é exercido o poder.

\subsection{A dimensão de gênero na construção da figura do juiz ideal}

Os estereótipos de gênero são perceptíveis na construção da figura do juiz ideal no imaginário jurídico. Nas formulações filosóficas a respeito dos atributos que constituem o bom juiz, são apresentados arquétipos que remetem a figuras heroicas, supra-humanas e masculinas ${ }^{27}$. Esse repertório simbólico desponta com clareza até mesmo na indumentária dos tribunais. As vestes talares estabelecem associações inconscientes com heróis e sacerdotes e buscam demonstrar que o juiz representa a instituição e tem a tarefa de julgar com imparcialidade, deixando de lado suas visões pessoais. Até mesmo a cor da toga é uma escolha política ${ }^{28}$ : o preto - que indica a ausência de cor e que não reflete as luzes que absorve - representa a imparcialidade judicial e o luto ${ }^{29}{ }^{30}$.

A produção no campo da filosofia do direito sobre os modelos de juiz ideal é ilustrativa da associação do ato de julgar com formas masculinas ${ }^{31}$. Um exemplo emblemático e muito conhecido é o modelo de juiz Hércules concebido por Ronald Dworkin. Em sua conhecida formulação sobre a "resposta certa" a ser dada nos casos difíceis, Dworkin expõe o conceito de direito como integridade. De acordo com o autor, a interpretação jurídica é uma atividade que reconstrói racionalmente as escolhas políticas por meio da atribuição de significado aos princípios. Para dar conta desse requisito de unidade e coerência do sistema, é apresentada a figura utópica do juiz Hércules, dotado de capacidades extraordinárias que o tornam apto a realizar a missão de interpretar o ordenamento jurídico levando em consideração todas as informações possíveis, conciliando o dinamismo requerido pelas transformações sociais com a necessidade seguir os precedentes ${ }^{32}$.

26 OKIN, Susan Moller. Gênero, o público e o privado. Estudos Feministas, Florianópolis, v. 16, n. 2, p. 305-332, maio/ago. 2008.

27 Como observa Clara da Mota Alves, a atividade de julgar é, na sua origem, projetada para homens, o que cria diversos tensionamentos entre as ordens pública e privada, sobretudo quando mulheres se tornam juízas. Nas palavras da autora, "[e]stes tensionamentos entre público e privado estão em permanente ação e comunicação. Não há dificuldade doméstica que não corresponda a um problema também no universo público, afinal estamos falando de ambientes e cargos inteiramente projetados para indivíduos que não deveriam ter nenhum tipo de responsabilidade familiar. Tudo isso se reflete na carga horária projetada como oficial para o trabalho, na falta crônica de creches e berçários nas dependências do Poder Judiciário, no desenho institucional das promoções e titularizações que, via de regra, ocasionam permanente mudança de sede de jurisdição. São inúmeros os exemplos e aspectos que densificam esta percepção de que o espaço público da magistratura é condicionado por um determinado modelo de vida privada hegemônica patriarcal e masculina". ALVES, Clara da Mota Santos Pimenta. Gênero, espaço público e poder: uma análise sobre a composição das comissões examinadoras de concurso da magistratura. Revista Publicum, Rio de Janeiro, v. 3, n. 1, p. $352-370,2017$. 28 Sobre os significados da cor preta na vestimenta, cf. HARVEY, John. Homens de preto. São Paulo: Unesp, 1995. p. 62.

29 ISAULA, Rodolfo. Toga de jueces, um luto de siglos. El Heraldo, abr. 2014. Disponível em: <http://www.elheraldo.hn/alfrente/566256-209/toga-de-jueces-un-luto-de-siglos>. Acesso em: 31 maio 2018.

30 Para um debate sobre a (in)adequação do uso das togas, cf. FRANK, Jerome. The cult of the robe. In: FRANK, Jerome. Courts on trial: myth and reality in american justice. Princeton: Princeton University Press, 1973. KENNEDY, Walter B. The cult of the robe: a dissent. Fordham Law Review, v. 14, n. 2, p. 192-196, 1945.

31 Aqui cabe um esclarecimento. Ao afirmarmos que a teoria jurídica costuma operar com modelos masculinos, levamos em consideração os arquétipos que personificam os ideais de comportamentos e atributos judiciais referenciados na filosofia contemporânea. Ou seja, apontamos os heróis que, na visão de filósofos do direito, seriam emulados pelos juízes reais. Essa apreciação não significa ignorar que mitos femininos também povoam a simbologia jurídica. O mais famoso mito relacionado à justiça e ao direito é a figura da deusa Têmis. Na cultura grega, ela corresponde à voz oracular que ensina piedade, equilíbrio e prudência. Ela encarna a lei divina, o direito e o costume. Nesse contexto, Têmis não funciona como um modelo de juiz, mas como um referencial abstrato da ideia de justiça a que os juízes devem estar sujeitos. É interessante notar que os códigos de ética judicial se referem aos juízes como "servos de Têmis". Cf. o art. 29 do Draft Code of Ethics of Judges da Comissão Europeia para a Democracia Através do Direito.

32 DWORKIN, Ronald. O império do direito. São Paulo: Martins Fontes, 1999. p. 294: "Nenhum juiz real poderia impor nada que, de uma só vez, se aproxime de uma interpretação plena de todo o direito que rege sua comunidade. É por isso que imaginamos um juiz hercúleo, dotado de talentos sobre-humanos e com um tempo infinito a seu dispor. Um juiz verdadeiro, porém, só pode imitar Hércules até certo ponto". 
O filósofo belga François Ost, em texto clássico e influente sobre os modelos de juiz relacionados às diversas etapas de evolução do pensamento jurídico ${ }^{33}$, recorre também às figuras mitológicas como alegorias explicativas das maneiras de julgar. $\mathrm{Na}$ sua construção metafórica, são apresentados três arquétipos. O juiz Júpiter é associado ao referencial positivista e à concepção do ordenamento como uma estrutura hierárquica, em cujo ápice está a Constituição. O juiz Hércules, que fora idealizado por Ronald Dworkin e é reconstruído por Ost, é aquele que decide os casos difíceis e pode encontrar a única resposta correta. O juiz Hermes, apresentado como o melhor modelo na visão do autor, é uma síntese dos anteriores. Ele atua em rede, como transmissor e tradutor da linguagem. Hermes é o mensageiro que ocupa o vazio das coisas e assegura a comunicação entre os personagens épicos. Ele é, de acordo com a mitologia grega, filho e mensageiro de Zeus, dotado de singular capacidade intelectual e de entendimento ${ }^{34}$. Age como mediador entre os Deuses do Olimpo e os mortais, trazendo a estes a vontade divina decodificada. Ele não conhece outra lei além dos discursos transmitidos e é com base neles que julga ${ }^{35}$.

Os modelos de juiz mencionados ganharam prestígio na teoria jurídica, ao ponto de pautar uma parte da discussão acadêmica no campo da hermenêutica ${ }^{36}$. As referidas construções, por um lado, são reveladoras de como o aparato alegórico imaginado na busca dos traços desejáveis no magistrado é estabelecido por meio de alegorias masculinas. Mas, por outro lado, as facetas heroica, sobrenatural e supra-humana dos arquétipos mitológicos revelam, também, a expectativa de que os juízes deixem de lado suas personalidades e traços individuais ao decidir. Essa perspectiva está presente em vários aspectos da idealização sobre a atividade de julgar. Ela desponta, por exemplo, na visão do positivismo legalista de que o juiz deve atuar estritamente subordinado à lei e que seu papel como intérprete consiste, apenas, em revelar o conteúdo preexistente da norma, despindo-se de suas perspectivas particulares ${ }^{37}$. Também nas togas que os magistrados vestem está embutida a mensagem subliminar de que suas singularidades pessoais devem ser deixadas do lado de fora das cortes.

Há traços de desumanização tanto nos modelos filosóficos ideais de juiz quanto no conjunto de qualidades que se espera que magistrados apresentem para serem percebidos como confiáveis e imparciais. De um lado, há uma expectativa de que possuam habilidades sobre-humanas - típicas dos heróis mitológicos - para decidir da melhor forma possível. De outro, o sistema é conformado para que as particularidades pessoais e os traços de falibilidade humana dos juízes sejam obliterados, ou, pelo menos, encobertos.

Esses elementos adquirem relevância na discussão sobre o significado e o impacto da presença de mulheres nas carreiras jurídicas, em geral, e na magistratura, em particular ${ }^{38}$. Na produção feminista, há um grupo de trabalhos que expõe a ideia de que mulheres possuem um estilo diferente e peculiar de argumentar e de julgar $^{39}$. Essas leituras derivam de um conhecido estudo de Carol Gilligan ${ }^{40}$, que, partindo de uma investiga-

33 OST, François. Júpiter, Hércules, Hermes: tres modelos de juez. Doxa: Cuadernos de Filosofía del Derecho, n. 14, p. 169-194, 1993.

34 Nesse sentido, veja-se: CAMARGO, Margarida Maria Lacombe. Interpretação constitucional. In: CAMARGO, Margarida Maria Lacombe. (Org.). 1988-1998: uma década de constituição. Rio de Janeiro: Renovar, 1999. p. 431.

35 OST, François. Júpiter, Hércules, Hermes: tres modelos de juez. Doxa: Cuadernos de Filosofía del Derecho, n. 14, p. 169-194, 1993. p. 189.

36 Título de exemplo, veja-se STRECK, Lenio. O pós-positivismo e os propalados modelos de juiz (Hércules, Júpiter e Hermes) dois decálogos necessários. Revista de direitos e garantias fundamentais, v. 7, p. 15-45, 2011. OLIVEIRA, Rafael Tomaz de. Decisão judicial e o conceito de princípio: a hermenêutica e a (in)determinação do direito. Porto Alegre: Livraria do Advogado, 2008. MOTTA, Francisco J. Borges. Levando o direito a sério: uma crítica hermenêutica ao protagonismo judicial. Florianópolis: Conceito, 2010.

37 Sobre o positivismo, cf. BOBBIO, Norberto. O positivismo jurídico: lições de filosofia do direito. São Paulo: Ícone, 1995.

38 Um amplo panorama dos debates envolvendo mulheres e a atividade de julgar pode ser conferido em FEENAN, Dermot. Editorial introduction: women and judging. Feminist Legal Studies, v. 17, p. 1-9, 2009. Uma análise sobre as teses que perfilham distinções entre a forma de julgar de homens e mulheres pode ser encontrada em KENNEY, Sally J. Thinking about gender and judging. International Journal of the Legal Profession, v. 15, n. 1-2, p. 87-110, mar./jul. 2008.

39 WILSON, Bertha. Will women judges really make a difference? Osgoode Hall Law Journal, v. 28, n. 3, p. 507-522, 1990. ABRAHAMSON, Shirley S. The woman has robes: four questions. Golden Gate Law Review, v. 14, n. 3, p. 489-503, 1984.

40 GILLIGAN, Carol. In a different voice: psychological theory and women's development. Cambridge: Harvard University Press, 2003. 
ção sobre o desenvolvimento da argumentação moral em crianças, sugere que meninas formulariam julgamentos éticos de forma distinta dos meninos. Alguns estudos nesse âmbito recorrem à personagem Portia, do Mercador de Veneza, de Shakespeare, para desenvolver a noção de que as mulheres têm uma voz típica e uma forma de raciocinar juridicamente distinta ${ }^{41}$. Dessa proposição advém a tese de que o incremento na participação feminina no judiciário repercutiria na forma como o direito é entendido.

Tal leitura, porém, não é largamente aceita ${ }^{42}$. Muitas formulações críticas afirmam, com razão, que a noção de que as mulheres possuem uma "voz diferente" parte de uma visão estereotipada e essencialista sobre o feminino. Argumenta-se que imaginar uma voz fundamentalmente feminina cria um modelo padronizado e reduzido, que acaba por discriminar as mulheres que não se enquadram nessa fórmula, além de reforçar a oposição entre masculino e feminino ${ }^{43}$. Não obstante, as questões formuladas por Gilligan tiveram o mérito de jogar luz sobre a falsa universalidade dos modelos de argumentação associados ao discurso jurídico, abrindo espaço para o debate sobre formas alternativas de deliberação ${ }^{44}$. Em última análise, foi colocada em cena a discussão sobre em que proporção as formas jurídicas promovem limitações reducionistas, que empobrecem a discussão ao rejeitar procedimentos distintos de argumentação ${ }^{45}$. Coloca-se, nesse tema, a questão sobre se a presença de mulheres nos tribunais traria outros pontos de vista, alargando o campo de visão do direito e promovendo transformações no pensamento jurídico. Pondera-se que o horizonte do direito seria alargado pelo input de novas perspectivas, incluindo a experiência das mulheres inclusive no que se refere à vivência de "uma cultura jurídica que tende a desconfiar, não compreender e excluir" ${ }^{46}$ elas mesmas.

Nesse ponto entra em cena outra metáfora literária. Erica Rackley, ao explorar esses problemas, coloca em pauta o fato de que as pessoas com perspectivas diferentes, quando inseridas em ambientes que tendem a uniformizar comportamentos e esvanecer a singularidade, sucumbem à tentação de se render, de se conformar e de reprimir as especificidades. Para descrever como se opera esse processo, a autora recorre ao conto A Pequena Sereia, de Hans Christian Andersen. A sereia, que habitava as profundezas do mar, apaixona-se por um príncipe após salvá-lo de um naufrágio. Para ter a chance de se aproximar dele, ela precisa assumir a forma humana. Pede, então, ajuda à bruxa, que lhe oferece uma poção que transformará sua cauda de peixe em pernas. Esta, porém, adverte à sereia que caminhar será tão doloroso como pisar em facas afiadas, e exige em troca da poção que lhe entregue sua voz. A sereia aceita a troca e se lança no universo humano emudecida, assumindo com isso o risco de sequer ser notada pelo príncipe. Para Rackley, a sereia é uma alegoria mais adequada para explanar a relação dos juízes (e sobretudo das juízas) com o sistema jurídico do que o mito de Hércules. O juiz ideal no imaginário jurídico é aquele que transcende, apaga ou nega o seu

41 V., por exemplo, MENKEL-MEADOW, Carrie. Portia in a different voice: speculations on a women's lawyering process. Berkley Journal of Gender, Law \& Justice, v. 1, n. 1, p. 39-63, 1985.

42 Críticas ao entendimento de Carol Gilligan podem ser conferidas SENCHUK, D.M. Listening to a different voice: a feminist critique of Gilligan. Studies in Philosophy and Education, v. 10, n. 3, p. 233-249, 1990. COLBY, Anne; COLBY, Anne; DAMON, William. Listening to a different voice: a review of Gilligan's "in a different voice". Merrill-Palmer Quarterly, v. 29, n. 4, p. 473-481, oct. 1983. GREENO, Catherine G.; MACCOBY, Eleanor E. How different is the “different voice”?. Signs, v. 11, n. 2, p. 310-316, 1986. 43 Sobre a crítica ao essencialismo, cf. CONAGHAN, J. Reassessing the Feminist Theoretical Project in law. Journal of Law \& Society, v. 27, n. 3, p. 351-385, 2000. Gilligan rejeita essas críticas, argumentando que, embora seu trabalho tenha abordado empiricamente as mulheres, a associação não seria absoluta ou necessária. Nas palavras da autora, "[m]y questions are about voice and relationship. And, my questions are about psychological processes and theory, particularly theories in which men's experience stands for all of human experience-theories which eclipse the lives of women" and shut out women's voices. I saw that by maintaining these ways of seeing and speaking about human lives, men were leaving out women, but women were leaving out themselves." GILLIGAN, Carol. In a different voice: psychological theory and women's development. Cambridge: Harvard University Press, 2003.

44 RACKLEY, Erika. Representations of the (woman) judge: Hercules, the little mermaid, and the vain and naked Emperor. Legal Studies, v. 22, n. 4, p. 602-624, nov. 2002. BERNS, Sandra. To speak as a judge: difference, voice and power. Dartmouth: Ashgate, 1999. 45 "While all law students - male and female - are subject to this process of alienation, for women it is a peculiarly distorting experience, as the self they strive to become is imbued with gendered cultural signifiers which render unstable their newly acquired sense of legal identity". RACKLEY, Erika. Representations of the (woman) judge: Hercules, the little mermaid, and the vain and naked Emperor. Legal Studies, v. 22, n. 4, p. 602-624, nov. 2002.

46 RACKLEY, Erika. Representations of the (woman) judge: Hercules, the little mermaid, and the vain and naked Emperor. Legal Studies, v. 22, n. 4, p. 612, nov. 2002. 
ego, submetendo-o a algo mais grandioso e elevado ${ }^{47}$. Em suas palavras:

Ela [a juíza mulher] também permanece como uma sereia. Sua aparência física ameaça perturbar as normas estéticas; sua presença é uma irritação inescapável, simultaneamente confirmando e criando uma disjunção à masculinidade estabelecida no poder [judiciário]. Como tal, a mulher juíza é quase uma contradição em termos. Ela é tão desviante que está inevitavelmente sujeita a um desejo irreprimível de se conformar. Como a sereia de Andersen, ela é induzida a negar a si mesma e vender sua voz; sua chamada de sirene perigosa é silenciada e no silêncio a diferença é perdida. ${ }^{48}$

A imagem da sereia como metáfora do apagamento da individualidade escancara uma dificuldade da discussão sobre a carência de diversidade na composição dos tribunais ${ }^{49}$. $\mathrm{O}$ funcionamento do direito em geral - e, de forma ainda mais intensa, a lógica dos julgamentos - encerra um ideal de imparcialidade e objetividade que demanda a alienação da personalidade, criando uma exigência de auto-obliteração vinculante tanto para os homens como para as mulheres ${ }^{50}$.

Nesse contexto, é importante enfatizar que debater diversidade no âmbito no judiciário, em larga medida, pressupõe contestar o mito de que os "juízes são oráculos de um direito mais elevado, um corpo de uma 'lei' absoluta e infalível", e que "simplesmente vestindo uma toga preta e fazendo o juramento de juiz, um homem deixa de ser humano e se despoja de todas as predileções, torna-se uma máquina pensante sem paixão" 51 .

É preciso, portanto, desprender-se do mito de que os juízes transcendem suas circunstâncias, reconhecendo que a forma como o direito é operado e aplicado é condicionada pelo seu passado e pelos pontos de vista dos intérpretes.

47 RACKLEY, Erika. Representations of the (woman) judge: Hercules, the little mermaid, and the vain and naked Emperor. Legal Studies, v. 22, n. 4, p. 614, nov. 2002.

48 Tradução livre. Lê-se, no original: "She [the woman judge] too remains cast as a mermaid. Her physical appearance threatens to upset aesthetic norms; her presence is an inescapable irritant, simultaneously confirming and disrupting the established masculinity of the bench. As such, the woman judge is almost a contradiction in terms. She is so deviant that she is inevitably subject to an irrepressible desire to conform. Like Andersen's mermaid, she is induced to deny herself and sell her voice; her dangerous siren call is silenced and in the silence difference is lost". RACKLEY, Erika. Representations of the (woman) judge: Hercules, the little mermaid, and the vain and naked Emperor. Legal Studies, v. 22, n. 4, p. 603, nov. 2002.

49 No Brasil, um estudo sobre profissionalismo na magistratura paulista descreve os processos aqui abordados: "Tal como já observado em outros estudos sobre as juízas, encontram-se narrativas que negam a persistência das diferenças de gênero na carreira. Entendemos esta visão como uma forma de atuar sobre o processo de formação da subjetividade e modelar a identificação profissional. Ativamente, elas afirmam o apagamento das diferenças, a partir da experiência da conquista de posições de poder, elevando o status social que a sociedade nega à mulher. $\mathrm{O}$ enfrentamento discursivo ocorre entre o apagamento e a visibilidade do gênero, seja ao apontar o preconceito ou ao essencializar o gênero, atribuindo às magistradas as marcas do feminino que fragilizam a carreira. Quanto à sexualidade, a invisibilidade é a forma hegemônica de tribunal lidar com essa diferença, não havendo ambivalência nos sinais emitidos sobre ela como registramos para o gênero.” BONELLI, Maria da Glória. Profissionalismo e diferença de gênero na magistratura paulista. Civitas, Porto Alegre, v. 10, n. 2, p. 290, maio/ago. 2010.

50 GILLIGAN, Carol. In a different voice: psychological theory and women's development. Cambridge: Harvard University Press, 2003. p. x: "'If I were to speak for myself,' a graduate student said one day in the middle of her oral exam-and then stopped. Hearing the sound of dissociation-the separation of herself from what she was saying, she began to question her relationship to what she was saying and what she was not saying. For whom was she speaking, and where was she in relation to herself? In the immediate aftermath of the Roe v. Wade decision, many women were openly questioning the morality of the Angel in the House-that nineteenth-century icon of feminine goodness immortalized by the poet Coventry Patmore: the woman who acts and speaks only for others. Discovering through experience the consequences of not speaking in relationships-the trouble that selfless behavior can cause-women were exposing the morality of the Angel as a kind of immorality: an abdication of voice, a disappearance from relationships and responsibility. The voice of the Angel was the voice of a Victorian man speaking through a woman's body. Virginia Woolf's realization that she had to strangle this Angel if she were to begin writing illuminates women's need to silence false feminine voices in order to speak for themselves.".

51 Tradução livre. Lê-se, no original: "Much harm is done by the myth that, merely by putting on a black robe, and taking the oath of office as a judge, a man ceases to be human and strips himself of all predilections, becomes a passionless thinking machine". FRANK, Jerome. The cult of the robe. In: FRANK, Jerome. Courts on trial: myth and reality in american justice. Princeton: Princeton University Press, 1973. p. 414. 


\section{A baixa representatividade de GÊnero nas CúPULAs do Judiciário e na Justiça Federal}

Quando se aborda o déficit de diversidade de gênero no judiciário, é lugar comum a afirmação de que esta surgirá, no futuro, como um desdobramento natural e incoercível da inclusão das mulheres no mercado de trabalho. Em outras palavras, mais diversidade de gênero nos órgãos judiciais de cúpula seria uma mera questão de tempo ${ }^{52}$, algo que brotaria como um efeito natural e automático da chegada das mulheres nas profissões jurídicas. Contudo, os dados atuais sobre a presença feminina nesse ramo de poder vêm demonstrando que o tempo, por si só, não é um fator decisivo para assegurar um crescimento proporcional da representatividade ${ }^{53}$. Quase vinte anos depois da virada do milênio, o equilíbrio de gênero nos espaços de poder parece, ainda, um horizonte incerto e remoto. A paisagem no judiciário brasileiro como um todo não sugere que haja um ritmo de evolução irrefreável em direção à paridade. Vale notar que, nos últimos anos, o Brasil caiu de posição no ranking de Igualdade de Gênero elaborado pelo Fórum Econômico Mundial. Em 2006, na primeira edição da pesquisa, o país ficou em $67^{\circ}$. Em 2015, o país ficou na posição 85. Em 2016, na 79. Já em 2017, caiu para a posição $90^{54}$.

Nesse tópico, apresentamos dados dos tribunais superiores brasileiros e da Justiça Federal, que constituem uma amostra ilustrativa do déficit de diversidade de gênero em segmentos importantes do judiciário nacional. A escolha de examinar os dados de tribunais superiores brasileiros deve-se ao fato de que o acesso a essas cortes se dá por critérios preponderantemente políticos, não havendo a possibilidade de neles ingressar por antiguidade nem por concurso público. O uso de dados da Justiça Federal, por sua vez, se justifica: (i) por serem dados muito recentes, produzidos pela Comissão AJUFE Mulheres; (ii) pelo fato de a Justiça Federal ser um ramo poder judiciário que passou por amplo crescimento e reformulação com a Constituição de 1988 (o Tribunal Federal de Recursos foi extinto e criaram-se cinco Tribunais Regionais Federais), de modo que o marco normativo que a rege é, na origem de seu desenho atual, o princípio da igualdade entre homens e mulheres; e (iii) por serem apenas cinco tribunais, é mais simplificada a análise do impacto dos critérios políticos no acesso ao tribunal (promoção por mérito), quando comparadas à promoção por antiguidade ${ }^{55}$.

A inserção das mulheres no universo jurídico é um fenômeno recente. A primeira advogada no Brasil, Myrthes Gomes de Campos, só foi registrada no Instituto dos Advogados do Brasil em 1906, apesar de ter concluído o bacharelado em Ciências Jurídicas e Sociais em 1898 ${ }^{56}$. Apenas em 1954 o quadro de juízes passou a contar com uma mulher, Thereza Grisólia Tang, que ouviu do presidente do Tribunal de Justiça de Santa Catarina que ela seria um "teste" ${ }^{\text {". A }}$ A primeira professora de direito no país, Bernadete Pedrosa, só

52 Para Marina Ito e Marília Scriboni, como os homens ocupam os cargos de cúpula há mais tempo e por conta das regras de promoção aos tribunais, que privilegiam os membros mais antigos da corte, a ascensão das mulheres à condição de desembargadoras seria vista em "pouco tempo". ITO, Marina; SCRIBONI, Marília. Em pouco tempo, mulheres estarão na cúpula da Justiça. Consultor Jurídico, mar. 2012. Disponível em: < https://www.conjur.com.br/2012-mar-08/aumenta-numero-mulheres-direito-sao-chegamcupula> . Acesso em: 28 maio 2018. Roberto Fragale Filho, Rafaela Moreira e Ana Paula Sciammarella adotam entendimento similar, apesar de afirmarem que "O significado e o alcance dessa chegada [das mulheres às cúpulas judicias brasileiras] ainda constitui um espaço de contenda”. FRAGALE FILHO, Roberto; MOREIRA, Rafaela Selem; SCIAMMARELLA, Ana Paula de O. Magistratura e gênero: um olhar sobre as mulheres nas cúpulas do judiciário brasileiro. E-cadernos CES, n. 24, p. 57-77, 2015.

53 Um panorama global pode ser encontrado na coletânea HEIDENSOHN, Frances (Ed.). Gender and justice: new concepts and approaches. Portland: Willan Publishing, 2006.

54 Os resultados globais estão disponíveis em: <http://reports.weforum.org/global-gender-gap-report-2017/results-and-analysis/>. Acesso: 26 maio 2018. Os demais dados estão disponíveis no site do Fórum: <http://reports.weforum.org>. Acesso em: 26 maio 2018.

55 Optamos por não analisar a promoção de juiz substituto para juiz titular. Por mais que, em regra, essa ascensão na carreira também se dê por antiguidade e por merecimento, na prática, os tribunais tratam dessa matéria de formas distintas. No TRF-2, por exemplo, as promoções ocorrem, predominantemente, por antiguidade.

56 GUIMARÃES, Lúcia Maria Paschoal; FERREIRA, Tania Maria Tavares. Myrthes Gomes de Campos (1875-?): pioneirismo na luta pelo exercício da advocacia e defesa da emancipação feminina. Revista do Instituto de Estudos de Gênero, Niterói, v. 9, n. 2, p. 135-151, 2009.

57 CONHEÇA a primeira mulher a ocupar o cargo de juíza no país. Donna, out. 2008. Disponível em: <http://revistadonna. 
começou a lecionar em $1965^{58}$. Já as posses da primeira ministra em tribunal superior (Cnéa Cimini Moreira) e da primeira ministra do Supremo Tribunal Federal (Ellen Gracie Northfleet) só ocorreram, respectivamente, em $1990^{59}$ e $2000^{60}$.

Em todos os ramos do judiciário brasileiro, o número de magistrados homens é superior ao de mulheres. O Censo do Poder Judiciário de 2014 indica que a média geral de magistrados é de 64,1\% contra 35,9\% de magistradas $^{61}$. Na Justiça do Trabalho, observa-se um certo equilibrio na composição - o que sugere que os fatores que determinam a baixa presença de mulheres não são associados à qualificação profissional, mas são razões outras que merecem ser estudadas -, mas, ainda assim, o coeficiente de mulheres é menor do que o de homens.

Os números relativos à diversidade de raça no judiciário como um todo revelam disparidades ainda mais profundas: $84,2 \%$ dos magistrados se declararam brancos, ao passo que apenas 15,6\% se declararam negros e $0,1 \%$, indígena ${ }^{62}$. O censo do $\mathrm{CNJ}$ é omisso quanto ao número de mulheres negras no poder judiciário ${ }^{63}$.

O gráfico abaixo detalha o percentual de magistrados em cada ramo do poder judiciário de acordo com o gênero:

Gráfico 1 - Percentual de magistrados segundo ramos do poder judiciário, de acordo com o gênero.

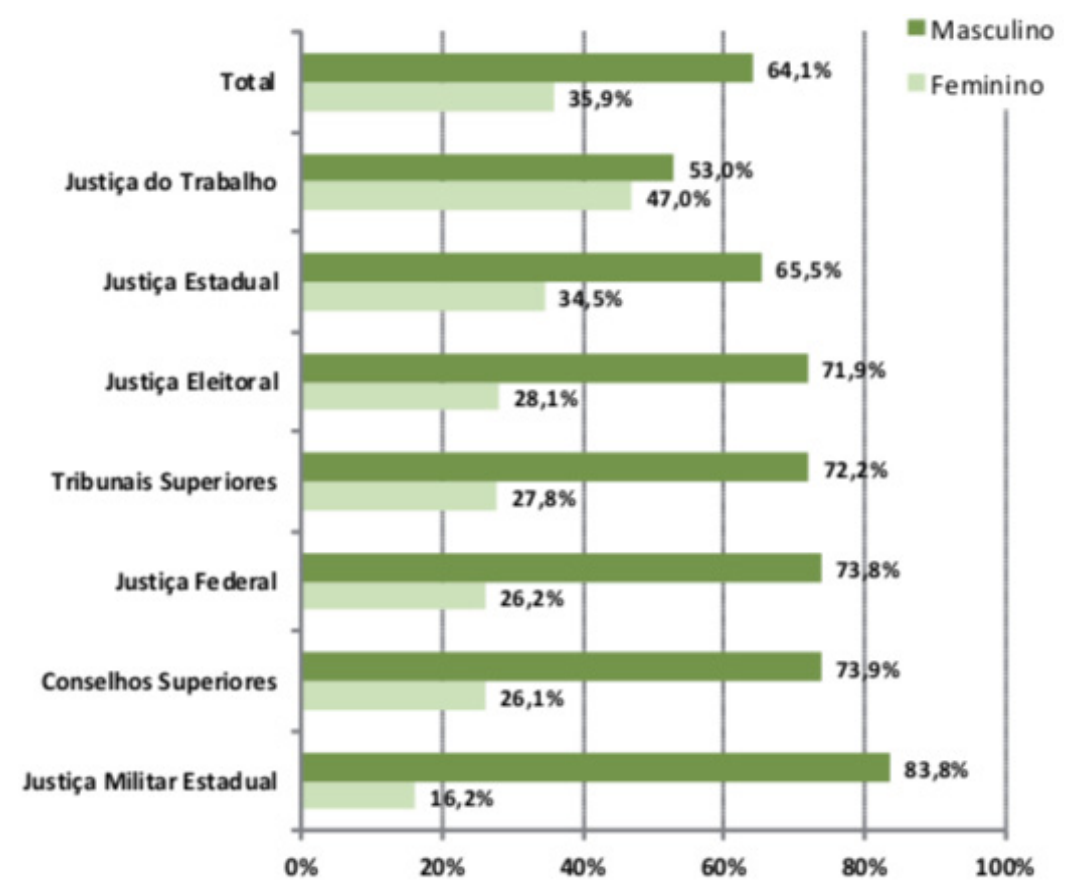

Fonte: BRASIL. Conselho Nacional de Justiça. Censo do Poder Judiciário: VIDE: Vetores iniciais e dados estatísticos. Brasília: CNJ, 2014. p. 37. Título original do gráfico: "Percentual de magistrados segundo tipo de carreira, por sexo. Brasil, 2013".

clicrbs.com.br/noticia/conheca-a-primeira-mulher-a-ocupar-o-cargo-de-juiza-no-pais/>. Acesso em: 29 maio 2018.

58 BERNADETE Pedrosa, a primeira mulher a ser admitida como professora da Faculdade de Direito do Recife em 1965. 2018. Disponível em: <https://www.ufpe.br/arquivoccj/curiosidades/-/asset_publisher/x1R6vFfGRYss/content/1965-primeiraprofessora-de-direito-no-recife/590249>. Acesso em: 29 maio 2018.

59 MORRE primeira mulher a ocupar cargo de ministra no TST. Consultor Jurídico, abr. 2008. Disponível em: < https://www.conjur.com.br/2008-abr-23/morre_primeira_mulher_ocupar_cargo_ministra_tst>. Acesso em: 28 maio 2018.

60 A TRAJETÓRIA da primeira mulher a integrar o Supremo. Consultor Jurídico, São Paulo, ago. 2011. Disponível em: < https:// www.conjur.com.br/2011-ago-11/ellen-gracie-trajetoria-primeira-mulher-integrar-supremo> . Acesso em: 29 maio 2018.

61 BRASIL. Conselho Nacional de Justiça. Censo do Poder Judiciário: VIDE: Vetores iniciais e dados estatísticos. Brasília: CNJ, 2014 . p. 37. 62 BRASIL. Conselho Nacional de Justiça. Censo do Poder Judiciário: VIDE: Vetores iniciais e dados estatísticos. Brasília: CNJ, 2014. p. 41.

63 Quanto às problemáticas raciais no judiciário, cf. CRUZ, Adriana Alves dos Santos; ALVIM, Alcione Escobar da Costa. As questões raciais e poder judiciário: enfrentamentos necessários. In: PIMENTA, Clara Mota et al. (Orgs.). Magistratura e equidade: estudos sobre gênero e raça no poder judiciário. Belo Horizonte: D’Plácido, 2018. p. 27-44. 
Uma análise da configuração dos tribunais superiores e dos tribunais federais sugere que a presença das mulheres em muitos setores no poder judiciário, especialmente nos estratos mais elevados, não acompanha o ritmo das transformações sociais. Observamos, nos números analisados, uma tendência à estratificação. É possível que esses dados sejam reflexo do fenômeno que estudos nesse campo qualificam como um "padrão de mecanismos internos de fechamento generificados nas profissões jurídicas" ${ }^{4}$. Mesmo quando ocorre aumento do coeficiente de mulheres nas instâncias inferiores, em decorrência dos modelos de recrutamento por concurso público ${ }^{65}$, a sub-representação permanece naqueles setores acessados por critérios nos quais preponderam avaliações subjetivas. Podemos observar que, nos órgãos compostos por nomeação política, os percentuais de mulheres são sistematicamente menores. No Brasil, o fenômeno é bastante claro. Nos contextos em que critérios políticos têm peso elevado, como nas promoções por merecimento e nomeações para tribunais superiores, o número de mulheres é menor. Atualmente, dos 93 ministros de tribunais superiores, por exemplo, apenas 16 são mulheres, o que representa um coeficiente de 17,2\%. A quantidade de mulheres nas cúpulas do judiciário reflete a baixa de mulheres em espaços de poder no Brasil (onde 50,67\% da população é composta por mulheres $\left.{ }^{66}\right)$. De forma similar, no poder legislativo brasileiro, em 2017 , havia apenas $10,7 \%$ de mulheres, o que fez com que o país ficasse na posição 154 do Ranking Mundial de Igualdade nos Parlamentos ${ }^{67}$ e em $32^{\circ}$ na América Latina ${ }^{68}$.

Em 2017, a Comissão AJUFE Mulheres, da Associação de Juízes Federais do Brasil (AJUFE), realizou pesquisa entre 185 magistradas federais de todos os cinco Tribunais Regionais Federais e apurou que, dentre as associadas que responderam ao questionário, mais de $86 \%$ consideram que a representatividade feminina é baixa ou razoável (no sentido de que houve avanços, mas há muito o que fazer) ${ }^{69}$. Dentre os fatores principais destacados pelas participantes para a presença reduzida de mulheres nos níveis mais altos da magistratura, estavam a dupla jornada e o rompimento da unidade familiar derivado da necessidade de mudar de residência em função do trabalho ${ }^{70}$. Além disso, o levantamento indicou a percepção, entre as magistradas consultadas, de que o ambiente judicial submete as mulheres a frequentes questionamentos sobre sua capacidade e performance. Muitas relatam que não basta serem aprovadas no concurso de seleção de magistrados e demonstrar um bom rendimento no trabalho: elas precisam, constantemente, mostrar que a condição feminina não interfere em seu desempenho, e que são capazes de exercer a atividade de julgar com

64 BOLTON, Sharon C.; MUZIO, Daniel. Can't live with 'Em; Can't Live without 'Em: gendered segmentation in the legal profession. Sociology, Chicago, v. 41, n. 1, p. 50, 2007.

65 Note que mesmo o concurso público ainda é permeado por problemas que demonstram como o preconceito de gênero opera no poder judiciário. Como observa Maria da Gloria Bonelli, na década de 1990, as provas para ingresso na magistratura eram identificadas com o nome do candidato, o que resultava em elevada eliminação de mulheres. Com a substituição do nome por números, cresceu o número de mulheres aprovadas nesta etapa, mas a prova oral e a entrevista com a banca ainda fazem com que a presença feminina decresça. BONELLI, Maria da Glória. Profissionalismo e diferença de gênero na magistratura paulista. Civitas, Porto Alegre, v. 10, n. 2, p. 106, maio/ago. 2010. Além disso, a presença de mulheres nas bancas de concurso público para ingresso na magistratura federal é praticamente nula (ALVES, Clara da Mota Santos Pimenta. Gênero, espaço público e poder: uma análise sobre a composição das comissões examinadoras de concurso da magistratura. Revista Publicum, Rio de Janeiro, v. 3, n. 1, p. 352-370, 2017.). Por conta disso, a conselheira do Conselho Nacional de Justiça (CNJ) Maria Tereza Uille Gomes emitiu, em 30 de maio de 2018, o Ofício n 79/GAB para o Conselho Nacional do Ministério Público (CNMP) solicitando a realização de estudos "sobre a viabilidade de edição de ato normativo ou Recomendação no âmbito deste Conselho, a fim de assegurar a (sic) percentual mínimo de participação feminina nos seguintes espaços: 1) Órgãos da administração superior; 2) Bancas de concurso para ingresso na carreira; 3) Nos painéis - na qualidade de expositora - de seminários, congressos e outros eventos acadêmicos".

66 Essa é a projeção de população feita pelo IBGE para o ano de 2018. Os dados estão disponíveis em: <https://www.ibge.gov. br/apps/populacao/projecao/>. Acesso em: 26 maio 2018.

67 UNITED NATIONS. Women in politics: 2017. 2017. Disponível em: < https://www.ipu.org/resources/publications/infographics/2017-03/women-in-politics-2017>. Acesso em: 30 maio 2018.

68 PODER Legislativo: porcentagem de mulheres no órgão legislativo nacional: Câmara baixa ou única. 2018. Disponível em: $<$ https://oig.cepal.org/pt/indicadores/poder-legislativo-porcentagem-mulheres-no-orgao-legislativo-nacional-camara-baixa-ou>. Acesso em: 30 maio 2018.

69 COMISSÃO AJUFE MULHERES. Nota Técnica: AJUFE mulheres 01/2017: resultados da pesquisa para se conhecer o perfil das associadas da AJUFE. Brasília: AJUFE Mulheres, 2017. p. 6.

70 COMISSÃO AJUFE MULHERES. Nota Técnica: AJUFE mulheres 01/2017: resultados da pesquisa para se conhecer o perfil das associadas da AJUFE. Brasília: AJUFE Mulheres, 2017. p. 9. 
excelência ${ }^{71}{ }^{72}$.

Outro aspecto, observado no gráfico 2, refere-se ao fato de que o aumento do coeficiente de mulheres nos órgãos de cúpula do poder judiciário brasileiro de 2000 a 2018 foi intermitente e que o percentual estagnou nos últimos dez anos. Ao contrário do pensamento comum mencionado no começo desse tópico, os dados apurados sugerem que a paridade de gênero no judiciário não é mera questão de tempo.

Os dados do CNJ no Censo do Poder Judiciário de 2014 deixam clara a dificuldade que as mulheres encontram para avançar na carreira da magistratura. Quando foi feito o levantamento, havia 42,8\% de juízas substitutas, ao passo que apenas $21,5 \%$ das mulheres eram desembargadoras ${ }^{73}$. Nesse sentido, nota-se a existência de um teto de vido (glass ceiling) no judiciário, como há em outros setores que envolvem poder ${ }^{74}$.

Em algumas cortes, a carência de diversidade é mais expressiva. No Tribunal Regional Federal da $5^{a}$ Região - que exerce jurisdição sobre os estados de Alagoas, Ceará, Paraíba, Pernambuco, Rio Grande do Norte e Sergipe -, desde 2014, não há nenhuma mulher na composição da $2^{\mathrm{a}}$ instância, que abarca 15 desembargadores federais ${ }^{75}$.

Outro exemplo é a Justiça Militar da União. Com mais de 200 anos de existência, o Superior Tribunal Militar teve apenas uma mulher na sua história, que ocupou a presidência durante 8 meses e a vice-presidência durante 1 ano e 3 meses (Maria Elizabeth Guimarães T. Rocha).

Confira-se gráfico que indica a proporção de magistradas nos tribunais superiores brasileiros:

71 Como destacou uma magistrada na pesquisa realizada pela Comissão AJUFE Mulheres, "[p]ara o homem muitas vezes basta apresentar um currículo apresentando seu amplo POTENCIAL. A mulher tem que provar seu DESEMPENHO excelente" (grifos no original). COMISSÃO AJUFE MULHERES. Nota Técnica: AJUFE mulheres 01/2017: resultados da pesquisa para se conhecer o perfil das associadas da AJUFE. Brasília: AJUFE Mulheres, 2017. p. 6.

72 Examinando outra realidade não abordada neste artigo, Maria Bonelli chegou a conclusões semelhantes. Como nota a autora, na magistratura paulista "encontram-se narrativas que negam a persistência das diferenças de gênero na carreira. Entendemos esta visão como uma forma de atuar sobre o processo de formação da subjetividade e modelar a identificação profissional. Ativamente, elas afirmam o apagamento das diferenças, a partir da experiência da conquista de posições de poder, elevando o status social que a sociedade nega à mulher." BONELLI, Maria da Glória. Profissionalismo e diferença de gênero na magistratura paulista. Civitas, Porto Alegre, v. 10, n. 2, p. 270-292, maio/ago. 2010.

73 BRASIL. Conselho Nacional de Justiça. Censo do Poder Judiciário: VIDE: Vetores iniciais e dados estatísticos. Brasília: CNJ, 2014. p. 37.

74 A imagem do teto de vidro é empregada para designar a barreira invisível que há, nas carreiras em geral, para que as mulheres possam obter cargos mais elevados e com rendimentos mais elevados. Tais barreiras são perceptíveis quando se faz uma análise geral de progressão na carreira, mas são invisíveis devido ao fato de os critérios internos de promoção em muitas empresas não serem públicos sequer para os próprios funcionários. Sobre o tema, cf MORRISON, Ann M.; WHITE, Randall P.; VELSOR, Ellen Van. Breaking the glass ceiling: can women reach the top of America's largest corporations?. 2. ed. Beverly: Basic Books, 1994. DAVIDSON, M. J.; COOPER, C. L. Shattering the glass ceiling: the woman manager. London: Paul Chapman Publishing, 1992. MOORE, Dorothy Perrin; BUTTNER, E. Holly. Women entrepreneurs: moving beyond the glass ceiling. Thousand Oaks: SAGE Publications, 1997.

75 A composição do Tribunal está disponível em: <http://www.trf5.jus.br/index.php?option=com_content\&view=article\&id= 661\&Itemid=241 > . Acesso em: 24 maio 2018. 
Gráfico 2 - Representatividade feminina nos tribunais superiores brasileiros.

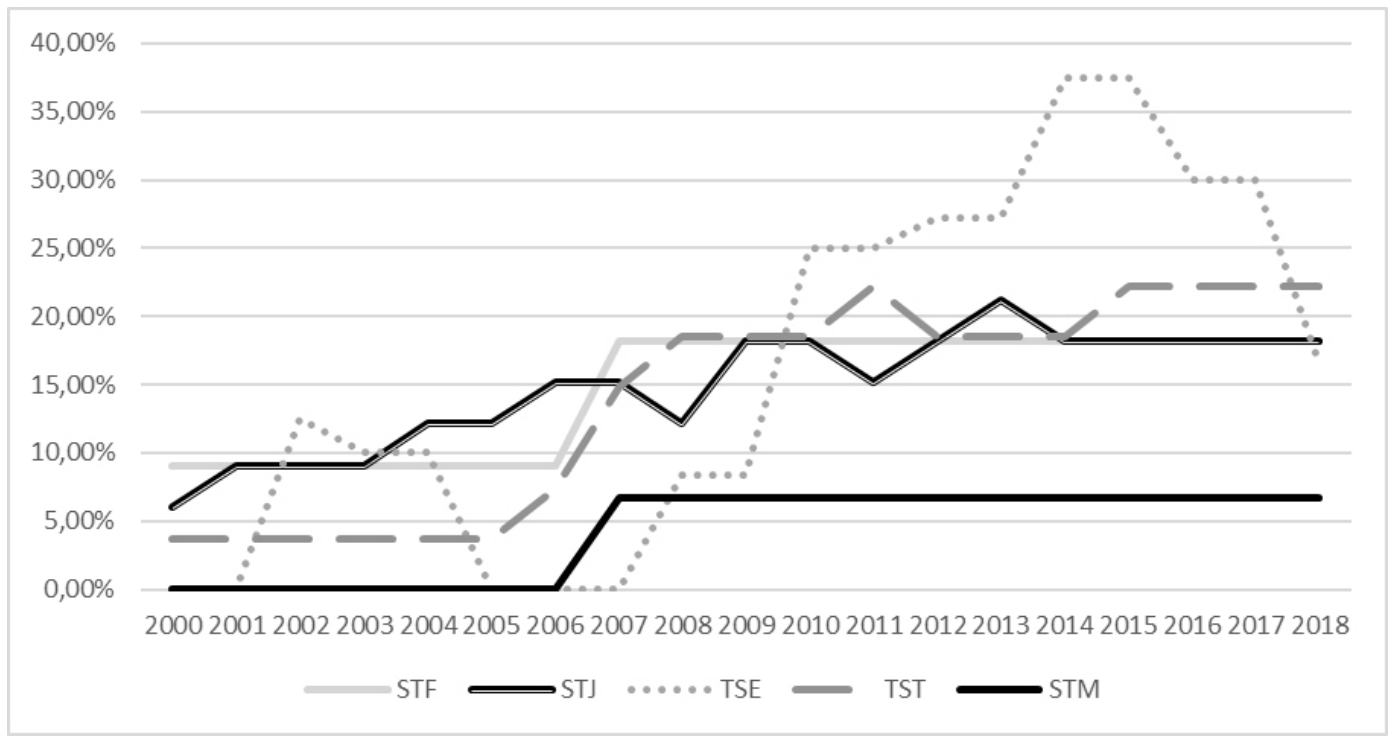

Fonte $^{76}$ : Sites dos tribunais. Elaboração própria.

Como se pode notar, no início do século XXI houve um crescimento significativo dos índices de presença feminina nos tribunais superiores. Todavia, nos últimos dez anos, verifica-se uma tendência à estabilidade em patamares médios que gravitam em torno de 15-16\%, o que sugere a estratificação.

Na magistratura federal, a quantidade de mulheres na carreira é visivelmente inferior à de homens. Nos níveis iniciais da carreira, as diferenças são perceptíveis, mas é na função de desembargador que se verifica maior assimetria:

Gráfico 3 - Presença feminina na magistratura federal, desde 1988.

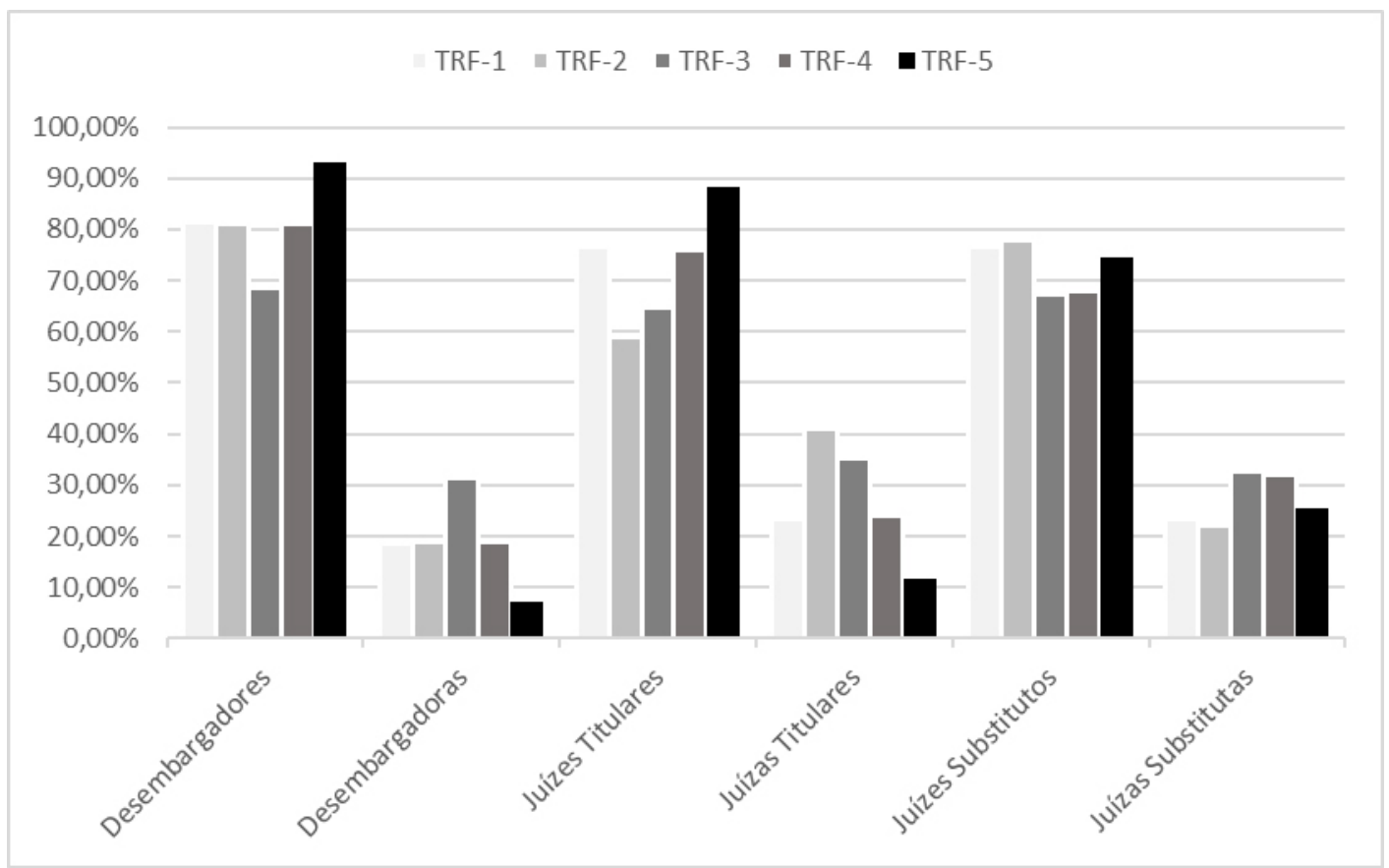

Fonte: Comissão AJUFE Mulheres. Elaboração própria.

76 Os dados referentes à composição anual dos tribunais foram obtidos a partir dos sítios eletrônicos oficiais de cada tribunal. Incluímos, no total de ministros dos tribunais, as vagas ociosas. Note que o número total de ministros no Tribunal Superior Eleitoral é variável. Utilizamos, como $100 \%$, o número total de magistrados para cada ano. 
Desbordaria dos limites e objetivos deste estudo explorar de forma sólida as razões para o desequilíbrio de gênero no judiciário. Todavia, no campo especulativo, é possível tangenciar algumas questões.

Os números gerais relativos à entrada no ensino superior e à sua conclusão sugerem que essas assimetrias não são relacionadas a diferenças na qualificação formal de homens e mulheres. Ainda que, desde o século $\mathrm{XX}$, a educação tenha se tornado fator primordial para a inserção social ${ }^{77}$, mais níveis de instrução formal não correspondem, automaticamente, a melhores posições na sociedade. Cerca de 55\% dos ingressantes em cursos de graduação presenciais são mulheres, ao passo que elas respondem por $60 \%$ dos concluintes ${ }^{78}$. No curso de Direito, em 2015, 55,3\% dos matriculados eram mulheres ${ }^{79}$ e o mesmo percentual indicava a quantidade de concluintes ${ }^{80}$. Em 2004, as mulheres já eram responsáveis por 56,4\% das matrículas na educação superior de forma geral ${ }^{81}{ }^{82}$. A frequência escolar no ensino médio também é superior quando se trata do sexo feminino ${ }^{83}$. Isso contraria a média salarial das mulheres, que é de $\mathrm{R} \$ 1.764,00$ contra $\mathrm{R} \$ 2.306,00$ dos homens ${ }^{84}$. Nos cursos de graduação em Direito, as mulheres também correspondem a mais de $50 \%$ dos alunos $^{85}$. A quantidade de cargos de gerência ocupados por elas também vai de encontro aos dados referentes aos níveis de educação: apenas 39,1\% de tais cargos são ocupados por mulheres ${ }^{86}$. Assim, por mais que as mulheres tenham conquistado inúmeros espaços, ainda há, nas esferas de poder e decisão, o fenômeno identificado como "masculinização do comando e feminização da subalternidade" de mando permanece fiel à lógica da cultura patriarcal".

$\mathrm{Na}$ análise sobre as causas da sub-representação feminina no judiciário de outros países, um amplo leque de fatores costuma ser aventado ${ }^{88}$. Especula-se sobre a existência de gargalos e vieses nos critérios de

77 MELO, Hildete Pereira de; THOMÉ, Débora. Mulheres e poder: histórias, ideias e indicadores. Rio de Janeiro: FGV, 2018. p. 93. 78 MULHERES são maioria no ingresso e na conclusão de cursos superiores. 2017. Disponível em: < http://www.brasil.gov. br/editoria/educacao-e-ciencia/2015/03/mulheres-sao-maioria-no-ingresso-e-na-conclusao-de-cursos-superiores?TSPD_101_R0 $=$ dee602bb551a76a45283dee5ab5e0d4cc1Q00000000000000000c279eb1 ffff00000000000000000000000000005b11770d0076024 db4>. Acesso em: 29 maio 2018.

79 INSTITUTO NACIONAL DE ESTUDOS E PESQUISAS EDUCACIONAIS. Censo da Educação Superior 2015: resumo técnico. Brasília: INEP, 2018. p. 23.

80 INSTITUTO NACIONAL DE ESTUDOS E PESQUISAS EDUCACIONAIS. Censo da Educação Superior 2015: resumo técnico. Brasília: INEP, 2018. p. 34.

81 INSTITUTO NACIONAL DE ESTUDOS E PESQUISAS EDUCACIONAIS. Censo da Educação Superior 2015: resumo técnico. Brasília: INEP, 2018. p. 34.

82 Uma análise da presença de mulheres nos cursos de graduação e de pós-graduação pode ser conferida em GUEDES, Moema de Castro. A presença feminina nos cursos universitários e nas pós-graduações: desconstruindo a idéia da universidade como espaço masculino. História, Ciências, Saúde - Manguinhos, Rio de Janeiro, v. 15, p. 117-132, jun. 2008.

83 INTITUTO BRASILEITO DE GEOGRAFIA E ESTATÍSTICA. Estatísticas de gênero: indicadores sociais das mulheres no Brasil. Estudos e Pesquisas - Informação Demográfica e Socioeconômica, n. 38, 2018.

84 Além disso, de acordo com dados do Ministério do Trabalho e Previdência Social, "[a]s mulheres com cinco a oito anos de estudo receberam por hora, em média, $\mathrm{R} \$ 7,15$, e os homens, com a mesma escolaridade, $\mathrm{R} \$ 9,44$, uma diferença de $\mathrm{R} \$ 24 \%$. Para 12 anos de estudo ou mais, essa diferença na remuneração vai a 33,9\%, com R $\$ 22,31$ para mulheres e R $\$ 33,75$ para homens”. MULHERES são maioria em universidades e cursos de qualificação. 2016. Disponível em: < http://www.brasil.gov.br/economia-e-emprego/2016/03/mulheres-sao-maioria-em-universidades-e-cursos-de-qualificacao?TSPD_101_R0=146a5e670db17b1d43690f8f6 5521871n6o00000000000000000c279eb1ffff00000000000000000000000000005b117bb600ea8281fc>. Acesso em: 29 maio 2018.

85 ALMEIDA, Rodolfo; ZANLORENSSI, Gabriel. Gênero e raça de estudantes do ensino superior no Brasil por curso e área. Nexo Jornal, dez. 2017. Disponível em: <https://www.nexojornal.com.br/grafico/2017/12/13/Gênero-e-raça-de-estudantes-doensino-superior-no-Brasil-por-curso-e-área>. Acesso em: 29 maio 2018.

86 INTITUTO BRASILEITO DE GEOGRAFIA E ESTATÍSTICA. Estatísticas de gênero: indicadores sociais das mulheres no Brasil. Estudos e Pesquisas - Informação Demográfica e Socioeconômica, n. 38, 2018.

87 A expressão é do Comitê de monitoramento da Aplicação da Convenção sobre a Eliminação de Todas as Formas de Discriminação Contra a Mulher. Cf. MELO, Mônica de; NASTARI, Marcelo; MASSULA, Letícia. A participação da mulher na magistratura brasileira. Disponível em: <http://www.spm.gov.br/assuntos/poder-e-participacao-politica/programas-acoes/desigualdades-entremulheres-e-homens/judiciario/dados_parciais_de_1999_a_20.pdf?TSPD_101_R0=58c632ceeac2b962cdb498af875432cdoB2000 00000000000000c279eb1ffff00000000000000000000000000005b11ef5d001b0182d8>. Acesso em: 28 maio 2018.

88 Sobre esse tópico, cf. KENNEY, Sally J. Thinking about gender and judging. International Journal of the Legal Profession, v. 15, n. 1-2, p. 87-110, mar./jul. 2008; RACKLEY, Erika. Women, judging and the Judiciary: from difference to diversity. New York: Routledge, 2013. KENNEY, Sally J. Gender \& justice: why women in the judiciary really matter. New York: Routledge, 2012. SCHULTZ, Ulrike; SHAW, Gisela (Ed.). Gender and judging. Oxford: Hart Publishing, 2013. 
seleção dos magistrados, sobre razões relacionadas à cultura das profissões jurídicas, bem como sobre os efeitos dos arranjos sociais mais abrangentes. Fala-se, também, nas dinâmicas corporativas de socialização, como confrarias ${ }^{89}$. De outro lado, são mencionados motivos culturais e pessoais, uma vez que as mulheres, muitas vezes, não buscariam posições mais elevadas ${ }^{90}$. Contudo, não é possível pensar nessas duas ordens de justificativa de forma apartada.

A configuração dos tribunais superiores sugere uma correlação entre maior peso das dinâmicas políticas na forma de ingresso e baixa representatividade feminina. Os critérios de seleção dos ministros são predominantemente políticos. A cúpula não é formada por um critério de ascensão interno à carreira do judiciário, de modo que não há acesso por antiguidade ou promoção por mérito. $\mathrm{O}$ critério passa por requisitos de idade, tempo de carreira, conhecimento jurídico e reputação ${ }^{91}$. Como visto no gráfico 2 , a presença feminina nesses tribunais é baixa.

De forma semelhante, são baixos os coeficientes de nomeações de mulheres nos tribunais regionais federais. Aqui, critérios políticos também exercem influência. É possível tornar-se desembargador desses tribunais de duas formas: i) por merecimento (critério no qual pesam fatores políticos e avaliações subjetivas); e ii) por antiguidade (critério puramente objetivo). Os dados mostram que a promoção de mulheres para os tribunais é baixa nos dois casos, mas quando as lentes se voltam para a promoção por merecimento, os números são ainda mais díspares:

89 BOHNET, Iris. What works: gender equality by design. London: Harvard University Press, 2016. p. 91.

90 RACKLEY, Erika. Women, judging and the Judiciary: from difference to diversity. New York: Routledge, 2013.

91 Para que um cidadão seja nomeado pelo Presidente da República como ministro do STF, após a aprovação da maioria absoluta do Senado Federal, é necessário ter mais de trinta e cinco anos e menos de sessenta e cinco anos de idade, ter notável saber jurídico e reputação ilibada (art. 101, CF). No STJ, os ministros devem ser "brasileiros com mais de trinta e cinco e menos de sessenta e cinco anos, de notável saber jurídico e reputação ilibada” (art. 104, CF). A nomeação do Presidente da República deve ser dentre os nomes constantes das listas tríplices elaboradas pelo próprio tribunal de juízes dos tribunais regionais federais e de desembargadores dos tribunais de justiça. Os demais membros devem ser, em partes iguais, dentre advogados e membros do Ministério Público Federal, Estadual, do Distrito Federal e Territórios, alternadamente, indicados na forma do art. 94. No STM, os ministros devem ser brasileiros com mais de trinta e cinco anos de idade, sendo "I - três dentre advogados de notório saber jurídico e conduta ilibada, com mais de dez anos de efetiva atividade profissional; II - dois, por escolha paritária, dentre juízes auditores e membros do Ministério Público da Justiça Militar". Os ministros devem ser "três dentre oficiais-generais da Marinha, quatro dentre oficiais-generais do Exército, três dentre oficiais-generais da Aeronáutica, todos da ativa e do posto mais elevado da carreira, e cinco dentre civis". (art. 123, CF). O TSE tem composição variável, devendo ter, no mínimo, sete membros. A escolha se dá: "I - mediante eleição, pelo voto secreto: a) três juízes dentre os Ministros do Supremo Tribunal Federal; b) dois juízes dentre os Ministros do Superior Tribunal de Justiça; II - por nomeação do Presidente da República, dois juízes dentre seis advogados de notável saber jurídico e idoneidade moral, indicados pelo Supremo Tribunal Federal." (art. 119, CF). Por fim, os ministros do TST devem ser brasileiros com mais de trinta e cinco anos e menos de sessenta e cinco anos, de notável saber jurídico e reputação ilibada. São nomeados pelo Presidente da República após aprovação da maioria absoluta do Senado Federal. A composição do tribunal deve ser de: "I um quinto dentre advogados com mais de dez anos de efetiva atividade profissional e membros do Ministério Público do Trabalho com mais de dez anos de efetivo exercício, observado o disposto no art. 94; (Incluído pela Emenda Constitucional n 45, de 2004) II os demais dentre juízes dos Tribunais Regionais do Trabalho, oriundos da magistratura da carreira, indicados pelo próprio Tribunal Superior. (Incluído pela Emenda Constitucional no 45, de 2004)." (art. 111-A, CF). 
Gráfico 4 - Promoção por merecimento, desde a criação dos tribunais.
Gráfico 5 - Promoção por antiguidade, desde a criação dos tribunais.
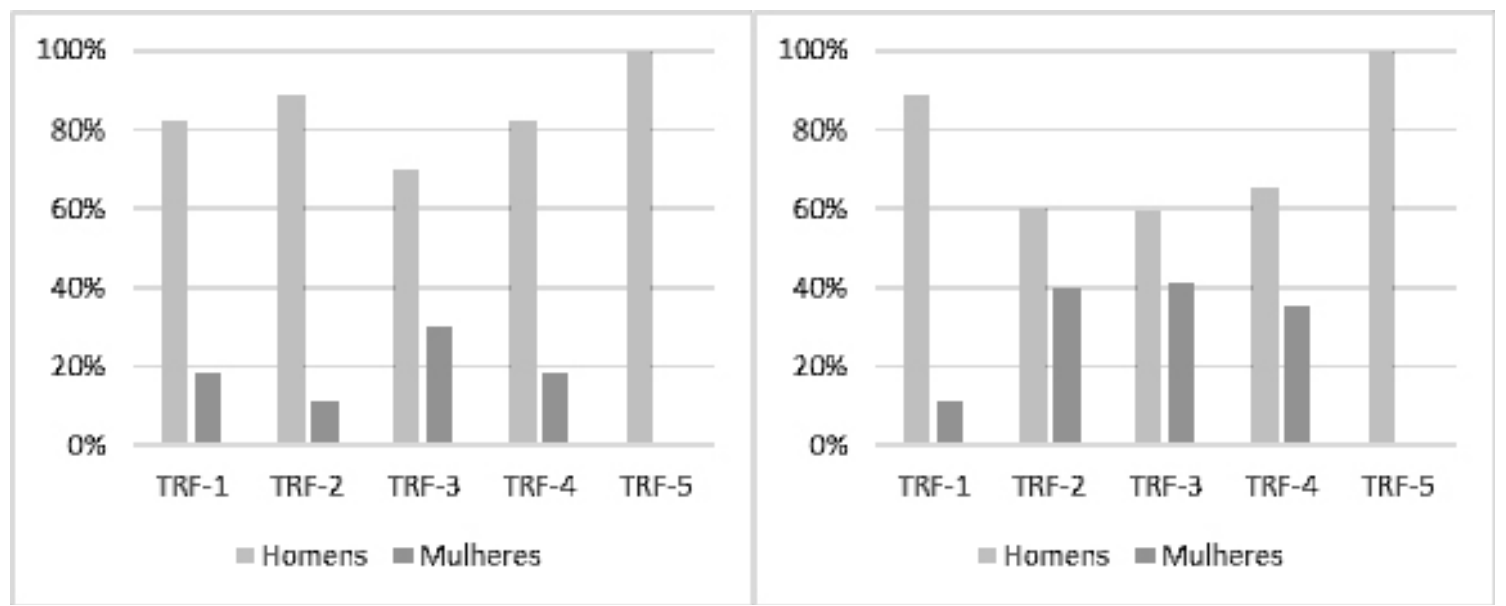

Fonte: Comissão AJUFE Mulheres. Elaboração própria.

Quando o acesso aos tribunais se dá por meio do quinto constitucional ${ }^{92}$, com maior peso de critérios políticos e subjetivos, a quantidade de mulheres é ainda menor. No TRF-1 e no TRF-2, apenas uma desembargadora que compõe cada corte atualmente ingressou pelo quinto constitucional. No TRF-4 e no TRF-5, não há sequer uma desembargadora que acessou o tribunal dessa forma. Já no TRF-3, há três desembargadoras que ingressaram por esse canal. As demais mulheres que fazem parte dos tribunais chegaram até eles por ascensão na própria carreira de magistratura. Confira-se o gráfico abaixo, que indica a quantidade de homens e mulheres nos TRFs e a forma com que acessaram os tribunais:

Gráfico 6 - Acesso aos TRFs, por gênero e por forma de ingresso, da composição de 2017.

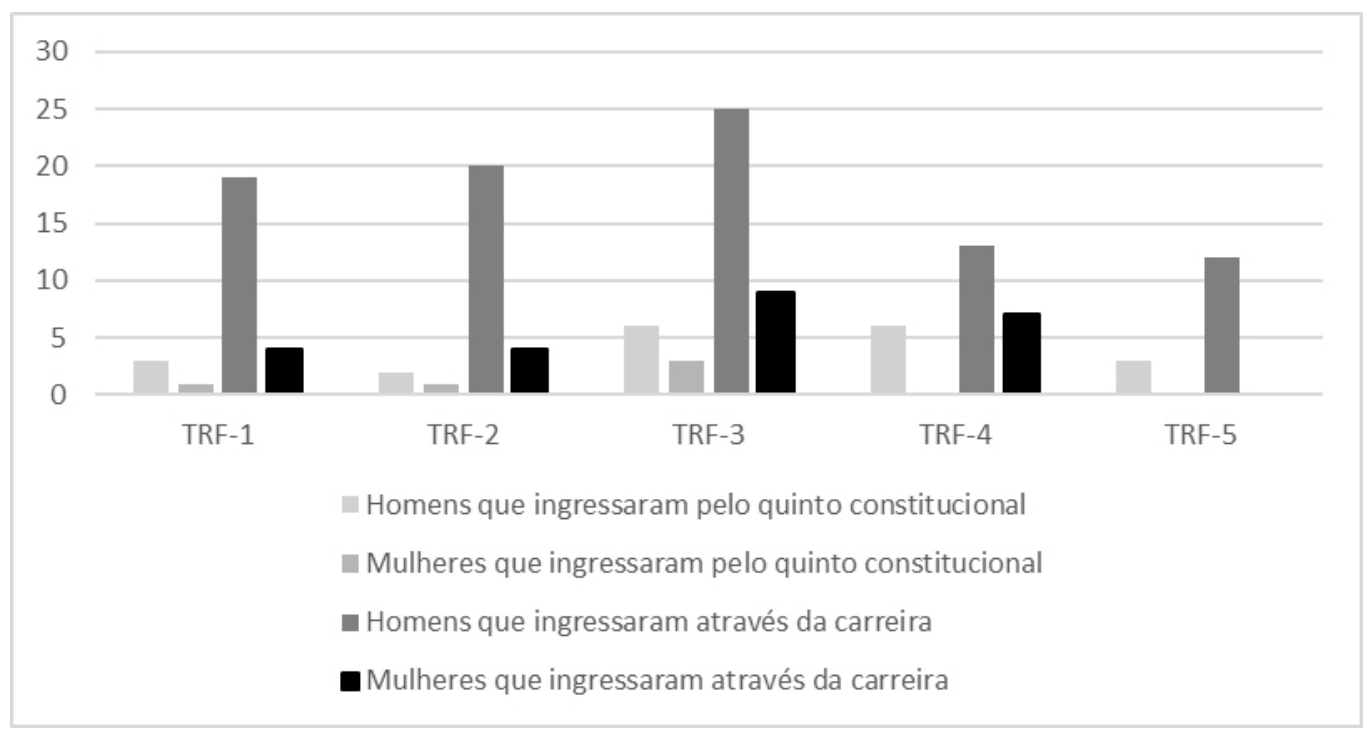

Fonte: Comissão AJUFE Mulheres. Elaboração própria.

92 Constituição Federal de 1988, Art. 94. "Um quinto dos lugares dos Tribunais Regionais Federais, dos Tribunais dos Estados, e do Distrito Federal e Territórios será composto de membros, do Ministério Público, com mais de dez anos de carreira, e de advogados de notório saber jurídico e de reputação ilibada, com mais de dez anos de efetiva atividade profissional, indicados em lista sêxtupla pelos órgãos de representação das respectivas classes.

Parágrafo único. Recebidas as indicações, o tribunal formará lista tríplice, enviando-a ao Poder Executivo, que, nos vinte dias subseqüentes, escolherá um de seus integrantes para nomeação". 
De acordo com os dados, o marcador gênero parece atuar como uma desvantagem competitiva nos processos políticos de promoção e de nomeação ${ }^{93}$. Nesse sentido, outro aspecto que precisa ser considerado é a ideia de que as promoções e seleções - tanto as calcadas em critérios exclusivamente políticos, quanto as que se dão de forma objetiva, mas que envolvem a análise pessoal do candidato em alguma etapa, como entrevista - operam com vieses cognitivos.

Entra em pauta, aqui, a reflexão sobre em que medida as decisões tomadas na esfera pública são pautadas pela razão. Os estudos de Economia Comportamental ${ }^{14}$ já demonstraram que as decisões humanas no geral não são particularizadas e formuladas racionalmente. Na realidade, as pessoas normalmente são irracionais e impulsionadas por tendências cognitivas (motivated reasoning/cognitive bias) na hora de tomar decisões. Daniel Kahneman ${ }^{95}$, vencedor do Prêmio Nobel de Economia, demonstrou, através de estudos realizados por anos, que nossas decisões raramente são tomadas de forma objetiva e com análises aprofundadas sobre as diversas alternativas. Sofremos o influxo de inúmeros fatores que diminuem nossa capacidade de julgar e de agir de forma racional. Segundo Kahneman, possuímos duas formas de pensar: uma rápida e pouco refletida (Sistema 1) e outra mais lenta, responsável por situações que exigem maior atenção (Sistema 2). Contudo, em alguns casos, decisões que demandariam a atuação da segunda forma de raciocinar seriam influenciadas por estereótipos e a reflexão não seria suficiente para superá-los.

Por mais que as pessoas queiram acreditar que suas decisões são, na maior parte do tempo, refletidas, os estudos têm mostrado que o Sistema 1 de pensamento é o que predomina. Não bastasse isso, as informações que temos a nosso dispor, nossas experiências e ideias influenciam no momento em que fazemos escolhas, ainda que de forma inconsciente ${ }^{96}$, sendo que, mesmo quando o Sistema 2 está atuando, depende de influxos do Sistema 1. Nesse sentido, por exemplo, as pessoas podem ser sugestionadas pela presença de advertências sobre os riscos para a saúde nas embalagens de produtos nocivos, bem como podem acreditar mais na probabilidade de repetição de um acontecimento se o tiverem vivido anteriormente do que se só tivessem lido a respeito em uma revista. Nesse panorama, desenvolveu-se a ideia de que seria possível criar determinadas influências positivas para que as pessoas fizessem a melhor escolha no momento de decidir ${ }^{97}$.

Dentre os diversos elementos que sugestionam as decisões e percepções das pessoas, há aquele que se baseia no gênero. Poderíamos enquadrar isso dentro do que em doutrina se conhece por viés da representatividade. Quando as pessoas são indagadas sobre se A deveria pertencer à categoria B, respondem após refletirem em que medida A é semelhante à imagem ou ao estereótipo que têm de B. Muitas vezes, essa heurística

93 Outro aspecto que merece uma análise cuidadosa é a quantidade de homens e mulheres que são convocados para atuar nos tribunais e quantos desses são promovidos a desembargadores por merecimento. Dados do TRF-1, por exemplo, indicam que há uma correlação entre esses números. Entre 2007 e 2017, 28 mulheres (16,96\%) e 137 homens (83,04\%) foram convocados para o tribunal. Desse total, $81,48 \%$ dos desembargadores promovidos no respetivo tribunal foram convocados anteriormente. Os dados a que tivemos acesso não fazem distinção por gênero quanto à promoção. Contudo, a partir desses dados é possível ter um indicativo de que esse é um campo de análise que merece ser explorado.

94 Sobre o tema, cf THALER, Richard H. Misbehaving: the making of behavioral economics. New York: W. W. Norton \& Company, 2016. CAMERER, Colin F.; LOEWENSTEIN, George; RABIN, Matthew (Eds.). Advances in behavioral economics. Princeton: Princeton University Press, 2004.

95 Cf. KAHNEMAN, Daniel; TVERSKY, Amos. Thinking, fast and slow. New York: Farrar Straus Giroux, 2013.; KAHNEMAN, Daniel; TVERSKY, Amos. The simulation heuristic. In: KAHNEMAN, Daniel; TVERSKY, Amos; SLOVIC, P. (Org.). Judgment under uncertainty: heuristics and biases. New York: Cambridge University Press, 1982. p. 201-208; TVERSKY, Amos; KAHNEMAN, Daniel. The framing of decisions and the psychology of choice. Science, v. 211, p. 453-458, 1981.

96 BANAJI, M.; GREENWALD, A. Blindspot: hidden biases of good people. New York: Delacorte Press, 2013.

97 Este é o modelo de ação que ficou conhecido como paternalismo libertário. De forma mais analítica, o governo não proíbe condutas nem compele o indivíduo a fazer algo que é bom para si mesmo, mas normatiza o contexto em que ele se insere, para o induzir a eleger a melhor alternativa. Trata-se de uma interferência do Estado na arquitetura da escolha, amparada na premissa de que nenhum ambiente de escolha é neutro. Assim, por exemplo, se, nas relações comerciais, os fornecedores tendem a sugestionar os consumidores a fazer as escolhas que tornam o negócio mais lucrativo, o governo poderia agir de forma a neutralizar essa influência, criando um panorama favorável à decisão que promova sua segurança ou saúde. THALER, Richard H.; SUNSTEIN, Cass R. Nudge: improving decisions about health, wealth, and happiness. New Haven: Yale University Press, 2008. SUNSTEIN, Cass R. Why nudge: the politics of libertarian paternalism. New Haven: Yale University Press, 2014. 
está certa, mas também pode provocar erros graves, o que se deve, principalmente, ao fato de que a maioria das pessoas não está disposta a admitir a probabilidade de que suas crenças arraigadas estejam erradas ${ }^{98}$. Nesse sentido, se socialmente predomina um padrão de pensamento enviesado de acordo com o qual as mulheres são associadas à família e ao trabalho doméstico e os homens, ao mundo dos negócios e à carrei$\mathrm{ra}^{99}$, esse modelo tenderá a motivar as decisões e julgamentos em variados cenários de forma insidiosa. Tais estereótipos atuam, muitas vezes, de forma implícita, afetando as mulheres em todas as esferas da vida ${ }^{100}$.

Nesse contexto, é preciso questionar se as próprias instituições e as fórmulas de acesso estão desenhadas e estruturadas de forma a favorecer o ingresso e a progressão na carreira de pessoas parecidas com aquelas responsáveis pelos processos de seleção e promoção. Como visto no item 1, o design dos órgãos estatais não é neutro. Para lidar com as desigualdades de gênero institucionalizadas, Iris Bohnet sustenta que é possível adotar mecanismos de design comportamental voltados para ambientes de preconceito (e não para pessoas individualmente consideradas), com foco nos locais de trabalho e em escolas ${ }^{101}$. A autora investiga quais as práticas institucionais vão de encontro à igualdade de gênero e, a partir disso, analisa formas de intervir no preconceito. Em outras palavras, recorre-se a nudges como meio de implementar uma política de paridade. Nessa fórmula, os indivíduos seriam encorajados a questionar suas ideias preconcebidas ao mesmo tempo em que a organização a que pertencem criaria novas formas de agir. Bohnet destaca que os anúncios de emprego e o próprio recrutamento para a composição do quadro de pessoal das organizações são generificados e permeados por discriminações, ainda que implícitas ${ }^{102}$. Nesse sentido, (re)delinear e (re)modelar os comportamentos dessas instituições pode ser uma forma de lidar com a desigualdade de gênero. Concomitantemente, é preciso incentivar nos indivíduos a autopercepção de que eles não devem agir de modo a anular suas perspectivas e individualidades em prol da assimilação da maioria. Caso contrário, o distanciamento entre aqueles que estão nos altos cargos em relação aos que se localizam nos cargos mais baixos seria acentuado e a igualdade estaria cada vez mais distante de ser atingida. Diante disso, a autora propõe práticas que promoveriam um maior engajamento do grupo e valorização das diferenças, como normas que promovam o empenho da equipe.

É possível aplicar essa forma de pensar e de combater a desigualdade também em ambientes mais amplos e em instituições políticas. Seriam adotadas normas sociais encorajadoras da compreensão do compor-

98 THALER, Richard H.; SUNSTEIN, Cass R. Nudge: improving decisions about health, wealth, and happiness. New Haven: Yale University Press, 2008. p. 26-31.

99 No Brasil, Maria Cândida Almeida explorou essa correlação de forma pioneira. Na avaliação da autora, esses preconceitos, que podem exercer influência no pensamento das próprias mulheres, impede que a presença feminina em espaços de poder seja mais elevada. Nas suas palavras: "Em razão dos vieses implícitos, tudo indica que os parâmetros de comparação entre homens e mulheres sejam mesmo distintos. E, como visto, as próprias mulheres não escapam desses preconceitos implícitos contra si. Isso as impede de protagonizar as mudanças estruturais que seriam necessárias para aumentar a sua representatividade nos espaços de poder. Não querem ser vistas como 'agressivas' ou 'confrontadoras' ou como alguém que requer tratamento especial. Cobramse mais e são mais cobradas. Sobre elas, impõem-se também expectativas quanto ao seu papel na família e o seu relacionamento com colegas e, por consequência, a sua exclusão do networking. Tais preconceitos também têm repercussão não só sobre relações profissionais entre magistrados e magistradas e o espaço que as juízas ocupam no Judiciário, como também sobre as interações com servidoras, estagiárias e advogadas”. ALMEIDA, Maria Cândida. Mulheres, vieses implícitos e o judiciário. Jota, mar. 2018. Disponível em: < https://www.jota.info/opiniao-e-analise/artigos/mulheres- vieses-implicitos-e-o-judiciario-12032018>. Acesso em: 29 maio 2018.

100 A título exemplificativo, cf. CECCHI-DIMEGLIO, P. How Gender Bias corrupts performance reviews, and what to do about it. Harvard Business Review, apr. 2017. Disponível em: <https://hbr.org/2017/04/how-gender-bias-corrupts-performancereviews-and-what-to-do- about-it>. Acesso em: 29 maio 2018. GVOZDANOVIC, J. Implicit bias in academia: a challenge to the meritocratic principle and to women's career - and what to do about it. League of European Research Universities, n. 23, 2018. LEE, Connie. Gender Bias in the Courtroom: combating implicit Bias against women trial attorneys and litigators. Cardozo Journal of Law \& Gender, v. 22, n. 229, p. 229-252, 2016. NEGOWET'TI, N. E. Implicit Bias and the legal profession's 'diversity crisis': a call for self-reflection. Nevada Law Journal, Las Vegas, v. 15, p. 431-460, 2015.

101 BOHNET, Iris. What works: gender equality by design. London: Harvard University Press, 2016.

102 Para solucionar o problema no recrutamento e na promoção de pessoal, Bohnet destaca três passos que deveriam ser tomados: i) avaliação comparativa e contratação e promoção em grupo; ii) exclusão de informações demográficas dos currículos (o gênero e a raça dos candidatos também poderiam ser retirados); e iii) entrevistas estruturadas para a avaliação dos candidatos. Cf. BOHNET, Iris. What works: gender equality by design. London: Harvard University Press, 2016. p. 123. 
tamento do outro e da forma de lidar com o grupo. Assim, Bohnet questiona os preconceitos inconscientes e o pensamento corrente a fim de enfrentar a desigualdade de gênero institucionalizada. Um exemplo de mecanismo fornecido pela autora é o encorajamento no sentido de mostrar às mulheres que elas podem atuar em "empregos de homem" sem perder sua feminilidade, como os Estados Unidos já fizeram. Até mesmo aspectos que podem parecer simples, como as paredes de quadros de dirigentes, diretores e afins, geram impactos na candidatura ou não de mulheres a determinados cargos ${ }^{103}$. Cotas de gênero também são vistas de forma positiva, já que garantem maior participação de indivíduos qualificados, mas sub-representados ${ }^{104}$.

Uma possível crítica que poderia ser levantada a essa tese consiste na ideia de que um ponto de vista feminista também pode ser considerado enviesado ${ }^{105}$. Todavia, na linha do que afirmamos até aqui, nenhuma perspectiva pode assumir a pretensão de neutralidade. O ponto de vista de quem formula um entendimento é sempre conformado pelas suas experiências e seu lugar no mundo. Nesse contexto, a contribuição que o raciocínio exposto neste estudo oferece é o de incentivar a reflexão sobre que tipos de vieses os variados pontos de vista incentivam. Para que tais vieses sejam, em alguma medida, superados, o primeiro passo é o seu reconhecimento. Escolhas racionais e informadas só se tornam possíveis quando a reflexão sobre as variáveis e preconceitos infiltrados no processo decisório é estimulada.

Paralelamente, reconhecer que as perspectivas, as pré-compreensões e os vieses determinam a forma pela qual decisões relevantes são tomadas nos permite repensar de que forma os critérios de escolha dos juízes dialogam com a noção de democracia. Se o ponto de vista dos agentes que formulam decisões é determinante, se sua biografia e experiências são elementos decisivos na arquitetura das escolhas e juízos que formularão, a discussão sobre a (falta de) legitimidade democrática de tribunais carentes de diversidade assume importância. Esse ponto é explorado no tópico a seguir.

\section{OS DILEMAS DA REPRESENTAÇÃO E POR QUE DIVERSIDADE IMPORTA}

Como visto nos tópicos anteriores, a identificação de estereótipos masculinos na formação da figura do juiz ideal e o diagnóstico sobre desequilíbrio de gênero nos tribunais abre um extenso campo de reflexão. É possível debater suas causas, desdobramentos e possíveis mecanismos de reversão. Porém, para que essas questões sejam assumidas como relevantes, uma pergunta crucial precisa ser enfrentada: por que diversidade na composição das instituições judiciárias importa?

Respostas a essa questão poderiam enveredar por múltiplas linhas. Seria possível, por exemplo, desde uma perspectiva de justiça constitucional substantiva, indagar se a configuração do judiciário revela violações ao princípio da igualdade e perquirir se há discriminações indiretas ${ }^{106}$ envolvidas nos processos de seleção e ascensão profissional das magistradas. Outra possibilidade seria, usando lentes institucionalistas e avaliações empíricas, pesquisar as potenciais consequências práticas de composições mais plurais na performance institucional das cortes ${ }^{107}$.

103 BOHNET, Iris. What works: gender equality by design. London: Harvard University Press, 2016. p. 201.

104 BOHNET, Iris. What works: gender equality by design. London: Harvard University Press, 2016. p. $204-219$.

105 Nesse sentido, o juiz da Corte da Inglaterra Jonathan Sumption sugeriu que vieses a favor da igualdade de gênero poderiam afastar homens talentosos da Corte. Cf. WALKER, Peter. Don't rush gender equality in UK judiciary, says supreme court judge. The Guardian, sep. 2015. Disponível em: <https://www.theguardian.com/law/2015/sep/22/gender-equality-warning- uk-legalprofession-supreme-court-judge-jonathan-sumption>. Acesso em: 31 maio 2018.

106 A ideia de discriminação indireta surgiu na seara trabalhista e, posteriormente, foi aplicada em diversos outros campos do Direito. Originou-se nos Estados Unidos, onde é conhecida como Teoria do Impacto Desproporcional (disparate impact theory). Sobre o tema, cf. CORBO, Wallace. Discriminação indireta: conceito, fundamentos e uma proposta de enfrentamento à luz da Constituição de 1988. Rio de Janeiro: Lumen Juris, 2017. HUNTER, Rosemary C.; SHOBEN, Elaine W. Disparate impact discrimination: american oddity or internationally accepted concept? Berkley Journal of Employment and Labor Law, v. 19, n. 1, p. 108-152, 1998. WILLBORN, Steven L. The disparate model of discrimination: theory and limits. American University Law Review, v. 34, p. 799-839, 1985.

107 Um amplo panorama das variadas pesquisas nesse campo pode ser encontrado em KENNEY, Sally J. Gender \& justice: why 
Esses campos de investigação, bem como outros não enumerados, são instigantes e merecem atenção. Nesse tópico, exploramos um aspecto teórico basilar relacionado à legitimação do poder dos tribunais. Defendemos a tese de que o atributo da diversidade na composição dos órgãos do poder judiciário deve ser compreendido como uma materialização do princípio democrático.

As democracias constitucionais contemporâneas foram edificadas a partir de promessas de promoção do pluralismo e igualdade. Nesse contexto, é natural o surgimento de demandas no sentido de que os órgãos do estado expressem coerência institucional, manifestando que esses valores estão presentes na sua própria composição. É intuitivo que a defesa normativa da diversidade na composição desses órgãos desponte como um desdobramento do próprio conjunto de valores pressuposto pelas democracias liberais ${ }^{108}$.

Essa linha de pensamento foi empregada recentemente por Lady Hale ${ }^{109}$, presidente da Suprema Corte do Reino Unido que durante oito anos foi a única juíza da corte ${ }^{110}$ :

Em uma democracia governada pelo povo e não por um monarca absoluto, ou mesmo por uma classe governante de aristocratas, o judiciário deve refletir a comunidade como um todo, e não apenas um pequeno segmento desta. Deve ser possível ao público sentir que as cortes são suas cortes; que seus casos estão sendo decididos e que o direito está sendo produzido por pessoas como eles, e não por alienígenas de outro planeta. No mundo moderno, onde a "deferência social" desapareceu em larga escala, isso deve potencializar em vez de minar a confiança do público no direito e no sistema jurídico.

A essa conexão mais ampla e intuitiva, que correlaciona diversidade e democracia, pode ser acrescentada uma outra perspectiva de análise. A discussão política costuma estabelecer uma ligação de sentido entre a ideia de representação e o princípio democrático. Nesse contexto, quando certo órgão do estado é rotulado como representativo, fica implícito que seu funcionamento atende a pressupostos democráticos. A correspondência de significado assumida no vocabulário contemporâneo é nítida: mais representação, geralmente, denota mais democracia.

Um exemplo dessa equivalência é a propagação da tese de que o judiciário angaria legitimidade democrática por também poder ser entendido como um poder representativo ${ }^{111}$. Essa discussão passou a circular de forma mais abrangente e literal na produção nacional a partir da defesa, por Robert Alexy ${ }^{112}$, da ideia de que o Judiciário age como representante argumentativo do povo. Para o autor, essa modalidade de representação opera de forma complementar e dialética à representação volitiva parlamentar ${ }^{113}$. No debate brasileiro, a tese se infiltrou na fundamentação das decisões do STF e na produção acadêmica. O ministro Gilmar Mendes, em decisões e entrevistas no ano de 2008, passou a sustentar que o Supremo atua como representante argumentativo da sociedade, para fundamentar a intromissão do Tribunal em questões difíceis ${ }^{114}$. De forma semelhante,

women in the judiciary really matter. New York: Routledge, 2012. p. 22.

108 Seguindo um itinerário diferente, mas concluindo que a razão fundamental para justificar o incremento da presença de mulheres no judiciário é a democracia, v. MALLESON, Kate. Justifying gender equality on the bench: why difference won’t do. Feminist Legal Studies, v. 11, p. 1-24, 2003.

109 HALE, Brenda. Lady Hale gives the Fiona wolf lecture for the women lanyers' division of the Law Society: women in the Judiciary. 2014. Disponível em: <https://www.supremecourt.uk/docs/speech-140627.pdf>. Acesso em: 27 maio 2018.

110 Em outubro de 2017, Lady Black tornou-se a segunda Juíza da Suprema Corte do Reino Unido.

111 EISGRUBER, Christopher L. Constitutional self-government. Cambridge: Harvard University Press, 2001.

112 ALEXY, Robert. Balancing, constitutional review and representation. International Journal of Constitutional Law, v. 3, n. 4, p. 572-581, out. 2005.

113 Alexy sustenta que, paralelamente à representação volitiva e decisória dos Parlamentos, um modelo de democracia discursiva deve conter elementos de representação argumentativa. Desse modo, enquanto a representação política parlamentar é pautada na intersecção desses dois aspectos representativos - instrumentalizados através do voto, da deliberação e da reeleição -, a representação exercida pelas Cortes Constitucionais é "puramente argumentativa", ou seja, pautada na persuasão e correção dos argumentos utilizados pelos magistrados, considerando que estes não são diretamente eleitos pela população. $\mathrm{O}$ autor pontua, todavia, que "a existência de argumentos bons e plausíveis não basta [...] para a representação. Para isso, é necessário que o tribunal não só promova a pretensão de que seus argumentos são os argumentos do povo ou do cidadão; um número suficiente de cidadãos precisa, pelo menos em perspectiva mais prolongada, aceitar esses argumentos como corretos." (tradução livre). ALEXY, Robert. Balancing, constitutional review and representation. International Journal of Constitutional Law, v. 3, n. 4, p. 580, out. 2005.

114 Confira-se a entrevista publicada em junho de 2008 no jornal Valor Econômico, na qual o Ministro, então presidente do STF, 
Thamy Pogrebinschi ${ }^{115}$ defendeu uma releitura da representação política, expandindo seus fundamentos e as condições de validade e legitimidade. Conectando o conceito de representação com as categorias da delegação, da accountability e da legitimação pelo resultado, a autora afirma que o conceito de representação pode ser aplicado ao judiciário. Em linha análoga, o ministro Luís Roberto Barroso ${ }^{116}$ tem desenvolvido, nos últimos anos, a ideia de que a jurisdição constitucional desempenha uma função representativa, paralelamente à contramajoritária ${ }^{117}$.

A tese de que o judiciário possui legitimidade democrática por funcionar como representante da sociedade, da forma como foi sustentada pelos ministros do STF, é permeada por dilemas. Ela encerra o risco de que juízes, ao invocarem o status de representantes como um fator de legitimação ex ante para agir em nome do povo, internalizem uma autoimagem institucional idealizada e divorciada da realidade. Nesse sentido, um papel representativo evocado pelos próprios juízes pode gerar um efeito contrário ao que a noção de representação democrática costuma perseguir. A experiência recente tem mostrado que "não é pequeno o risco de que esse conceito seja invocado e naturalizado com o propósito puramente persuasivo de invocar uma legitimação a priori da ação do Tribunal"118_119.

Não obstante, a ideia de que o judiciário tem uma faceta representativa pode operar como um ideal regulativo. Nessa perspectiva, a atuação representativa não deve ser entendida como um atributo inerente à função judicial ou como um fator de legitimação formal prévia, mas como um ônus institucional a ser perseguido pelas cortes, traduzido em um dever de abertura, porosidade e conformação do judiciário às demandas democráticas. Entendemos que descritivamente só será possível aferir se o Judiciário atuou de forma representativa por meio de análises retrospectivas sobre sua estruturação e funcionamento, que avaliem os impactos substantivos das decisões e as práticas processuais adotadas. Normativamente, o conceito de representação democrática do judiciário deve funcionar como um fator de avaliação das cortes quanto à transparência institucional, porosidade às demandas da sociedade civil e abertura a diversos de pontos de vista. Entendida sob essa perspectiva, a noção de representação argumentativa pressupõe que as cortes sejam institucionalmente estruturadas como organismos com composição plural.

afirma que este é “'Casa do povo' com a função de suprir as deficiências do Poder Legislativo, o Congresso Nacional”. BASILE, Juliano. Para p-l $\quad$-residente do STF, tribunal supre deficiências do Legislativo. Valor Econômico, São Paulo, jun. 2008. Disponível em: <http://www.valoronline.com.br/valoreconomico/285/primeirocaderno/politica/Para + o + presi dente+do+STF + tribunal + supre + deficiencias + do + Legislativo, ,60,4973950.html?highlight $=\& \quad$ newsid $=4973950$ \&areaid $=60 \&$ editionid $=2023>$. Acesso em: 27 maio 2018. No mesmo sentido, Gilmar Mendes se referiu aos juízes como “representantes argumentativos” da sociedade em seu voto prolatado no julgamento da ADI 3510-0.

115 POGREBINSCHI, Thamy. Judicialização ou representação: política, direito e democracia no Brasil. Rio de Janeiro: Elsevier, 2011. p. 165-183.

116 BARROSO, Luís Roberto; MENDONÇA, Eduardo. A razão sem voto: o Supremo Tribunal Federal e o governo da maioria. Revista Brasileira de Políticas Públicas, v. 5, p. 23-50, 2015. BARROSO, Luís Roberto. Contramajoritário, representativo e iluminista: os papeis dos tribunais constitucionais nas democracias contemporâneas. Direito \& Práxis, Rio de Janeiro, 2017., Ahead of print. Apresentando uma visão crítica a esse entendimento, veja-se PEREIRA, Jane Reis Gonçalves. Representação democrática do Judiciário: reflexões preliminares sobre os riscos e dilemas de uma ideia em ascensão. Juris Poiesis, Rio de Janeiro, v. 17, p. 343-359, 2014.

117 “[O] fato é que um olhar reconstrutivo sobre a jurisprudência e a própria postura da Corte permite concluir que ela tem desenvolvido, de forma crescente, uma nítida percepção de si mesma como representante da soberania popular. Mais precisamente, como representante de decisões soberanas materializadas na Constituição Federal e difundidas por meio de um sentimento constitucional que, venturosamente, se irradiou pela sociedade como um todo". BARROSO, Luís Roberto; MENDONÇA, Eduardo. Retrospectiva 2012: STF entre seus papéis contramajoritário e representativo. 2012. Disponível em: < http://www.conjur.com. br/2013- jan-03/retrospectiva-2012-stf-entre-papeis-contramajoritario-representativo >. Acesso em: 27 maio 2018.

118 PEREIRA, Jane Reis Gonçalves. Representação democrática do Judiciário: reflexões preliminares sobre os riscos e dilemas de uma ideia em ascensão. Juris Poiesis, Rio de Janeiro, v. 17, p. 343-359, 2014. Há variações dessa ideia externadas em NONATO, Israel. O Supremo não é oráculo: conversas acadêmicas com Jane Reis. 2013. Disponível em: <http://www.osconstitucionalistas. com.br/jane-reis-o-supremo-nao-e-oraculo>. Acesso em: 29 maio 2018. e PEREIRA, Jane Reis Gonçalves. Retrospectiva direito constitucional 2008: a expansão do Judiciário e o constitucionalismo cosmopolita. Revista Direito do Estado, v. 13, p. 23-53, 2008. 119 Um exemplo desse uso do conceito ocorreu no julgamento da constitucionalidade da Lei de Biossegurança ADI nº 3510, em que o Ministro Gilmar Mendes afirmou que o STF "pode ser uma casa do povo, tal qual o Parlamento". 
O conceito de representação pode ser abordado sob um enfoque formal ou material ${ }^{120}$. Nesse sentido, podemos distinguir representação técnico-jurídica e representação política. No primeiro sentido, jurídico-formal, todos os órgãos do estado são representativos, pois exercem poderes e funções em decorrência de uma autorização tácita dos cidadãos que deflui da própria estrutura e desenho das instituições. Na segunda abordagem, de ordem política, é pressuposto um nexo de legitimação genética entre a vontade do povo e o agir dos órgãos de representação democrática, que decorre do processo de designação eleitoral. Nesse segundo sentido, a representação pressupõe uma conexão do povo como as decisões tomadas pelos órgãos eleitos.

No clássico estudo de Hannah Pitkin ${ }^{121}$, que parte da segunda compreensão, são enumeradas quatro formas pelas quais a representação política costuma ser explicada ${ }^{122}$, que podem ser assim sintetizadas: i) representação formalista, que diz respeito à autorização que os órgãos estatais recebem dos cidadãos para agir, bem como da responsividade que possuem; ii) representação simbólica, na qual o foco recai sobre o grau de apoio e de correspondência às expectativas dos cidadãos que o representante possui; iii) representação descritiva ou identitária, de acordo com a qual as instituições do estado devem ser um espelho da composição social; e iv) representação substantiva, que destaca que os representantes devem atender às preferências e aos interesses dos representados.

A defesa de que os órgãos de cúpula do poder judiciário devem respeitar a pluralidade social, em geral, e a diversidade de gênero, em particular, coloca em foco o conceito de representação descritiva ou identitária. Além do gênero, que é o objeto central deste artigo, traços identitários como raça, religião, nacionalidade e origem também demandam atenção ${ }^{123}$. Para ter sua legitimidade reforçada, "é desejável, nas democracias plurais, que todos os órgãos do Estado reflitam simbolicamente os variados segmentos sociais"124. Nessa dimensão, assume importância que os representantes guardem alguma afinidade de características com os representados, de modo que os órgãos estatais reflitam as diferenças presentes na sociedade.

Partindo desse foco de análise, emerge uma conexão entre a representação descritiva e a legitimidade democrática do poder judiciário para interceder em questões submetidas às instâncias representativas eleitas. A associação entre legitimidade e diversidade na composição pode ficar clara, por exemplo, na preocupação de cortes supranacionais quanto à pluralidade de nacionalidade dos juízes ${ }^{125}$. Em sentido parecido, há, na Suprema Corte do Canadá, esforço para atingir uma representação continental e multiétnica: critérios geográficos são adotados para selecionar os magistrados da Corte ${ }^{126}$. Os novos modelos de constitucionalismo

120 De acordo com Ernst-Wolfgang Böckenförde, no sentido formal, representação significa a autorização que os órgãos de direção política recebem dos cidadãos. Nessa acepção, a representação é o "nexo de legitimação e de imputação que existe ou se estabelece entre a ação dos órgãos de direção e o povo". No sentido material, a representação se refere ao fato de que os cidadãos devem poder reconhecer-se nas ações dos órgãos de Estado, relacionando-se à "capacidade dos atos emanados do Estado de gerar aceitação e inclinação à obediência” (tradução livre). BÖCKENFÖRDE, Ennst-Wolfgang. Democracia y representación: crítica a la discusión actual sobre la democracia. In: BÖCKENFÖRDE, Ernst-Wolfgang. Estudios sobre el Estado de Derecho y la democracia. Madrid: Trotta, 1993. p. 145-146.

121 PITKIN, Hannah Fenichel. The concept of representation. Berkeley: University of California Press, 1967.

122 Destacando os quatro sentidos de representação aqui elencados, cf. PEREIRA, Jane Reis Gonçalves. Representação democrática do Judiciário: reflexões preliminares sobre os riscos e dilemas de uma ideia em ascensão. Juris Poiesis, Rio de Janeiro, v. 17, p. 343-359, 2014.

123 O chief constable inglês Peter Fahy fez interessante observação quanto à etnia dos julgadores, cuja importância variaria de acordo com o tema em debate: "When your house is burning down you are not interested in the ethnicity of the firefighter, but when it is a long term issue of youth alienation, countering extremism or dealing with complex matters such as female genital mutilation the ethnicity of the law enforcer makes a huge difference". O entendimento foi expresso por Peter Fahy em conversa com a juíza inglesa Lady Hale, como ela afirmou em palestra proferida em 2014. Disponível em: <https://www.supremecourt.uk/ docs/speech-140627.pdf>. Acesso em: 29 maio 2018.

124 PEREIRA, Jane Reis Gonçalves. Representação democrática do Judiciário: reflexões preliminares sobre os riscos e dilemas de uma ideia em ascensão. Juris Poiesis, Rio de Janeiro, v. 17, p. 352, 2014.

125 DANNENBAUM, Tom. Nationality and the international judge: the nationalist presumption governing the international judiciary and why it must be reversed. Cornell International Law Journal, v. 45, p. 77-184, 2012.

126 SONGER, Donald R. The transformation of the Supreme Court of Canada: an empirical examination. Toronto: University of Toronto Press, 2008. 
plurinacional também têm colocado a demanda de composição pluriétnica como um de seus desafios ${ }^{127}$.

Vale ressaltar que, na visão perfilhada no clássico estudo de Hannah Pitkin ${ }^{128}$, é o que uma instituição faz e não o que ela é que determina se é representativa. Todavia, compreensões mais inclusivas da representação legislativa, que envolvem a perspectiva das minorias, reconhecem a importância da inserção dos grupos historicamente excluídos do processo político como representantes ${ }^{129}$. De acordo com Anne Phillips, mesmo que os representantes promovam com eficiência os interesses dos marginalizados, isso não seria suficiente, por se tratar de uma proteção paternalista que perpetua a exclusão e mantém diminuído o status político dos excluídos da arena de representação. Nesse contexto, por mais bem-intencionados que sejam os representantes, determinados grupos de cidadãos permaneceriam alienados e infantilizados no processo decisório ${ }^{130}$. Essa noção de representação simbólica dos diversos grupos sociais como uma exigência democrática, construída em relação ao legislativo, também pode ser aplicada ao judiciário ${ }^{131}$.

Estudos acadêmicos têm demonstrado que fatores extrajurídicos influenciam na tomada de decisão por parte dos juízes ${ }^{132}$. Ainda que raramente se possa estabelecer correlações decisivas entre os entendimentos adotados e a identidade do juiz, algumas pesquisas sugerem que, pelo menos em questões sensíveis ao gênero, como discriminação, assédio sexual e violência doméstica, a mera presença de mulheres em órgãos colegiados interfere no resultado dos julgamentos, possivelmente porque a diversidade na composição exerceria impacto também nos entendimentos adotados pelos juízes homens ${ }^{133}$. No entanto, sob o ângulo da legitimação das cortes, não são apenas os resultados dos julgamentos que importam. O argumento mais consistente em favor da pluralidade de composição não decorre da convicção de que cortes heterogêneas vão produzir julgamentos mais acertados, mas da circunstância de que o equilibrio de gênero torna os tribunais mais legítimos sob a ótica democrática.

O caso Hobby Lobby ${ }^{134}$, decidido pela Suprema Corte dos Estados Unidos em 2014, exemplifica como o gênero na composição das Cortes pode repercutir na percepção social sobre o entendimento adotado pelos juízes em questões sensíveis nesse campo. Estavam em discussão as formas pelas quais mulheres poderiam obter acesso a diferentes métodos anticoncepcionais nos planos de saúde oferecidos por empresas. A decisão da Corte foi no sentido de que pequenas empresas poderiam invocar a liberdade religiosa para não serem obrigadas a custear formas de contracepção que conflitem com crenças de seus proprietários. Esse entendimento, porém, deu-se por meio de apertada maioria. Foram cinco votos corroborando essa opinião e quatro votos contrários, dos quais três foram das juízas que integram a corte. A juíza Ruth Ginsburg, que redigiu o voto dissidente, afirmou, posteriormente, que "os juízes homens não compreendem o que Hobby Lobby significou para as mulheres" ${ }^{135}$. Tal episódio, ainda que não possa ser tomado como indicativo da existência de um nexo de causalidade entre o gênero dos julgadores e seus entendimentos, explicita que a baixa diversidade na composição das cortes pode suscitar inquietações que repercutem na percepção exter-

127 TIERNEY, Stephen. We the peoples: constituent power and constitutionalism in plurinational states. In: WALKER, Neil;

LOUGHLIN, Loughlin (Org.). The paradox of Constitutionalism. Oxford: Oxford University Press, 2007, p. 229-246. p. $229-246$.

128 PITKIN, Hannah Fenichel. The concept of representation. Berkeley: University of California Press, 1967.

129 PHILLIPS, Anne. The politics of presence. Oxford: Oxford University Press, 1995.

130 PHILLIPS, Anne. The politics of presence. Oxford: Oxford University Press, 1995. p. 39.

131 Nesse sentido, MALLESON, Kate. Justifying gender equality on the bench: why difference won’t do. Feminist Legal Studies, v. 11, p. 1-24, 2003. KENNEY, Sally J. Gender \& justice: why women in the judiciary really matter. New York: Routledge, 2012.

132 V., por todos, MELLO, Patrícia Perrone Campos. Nos bastidores do Supremo Tribunal Federal: Constituição, emoção, estratégia e espetáculo. São Paulo: GEN, 2015.

133 BOYD, Christina L.; EPSTEIN, Lee; MARTIN, Andrew D. Untangling the causal effects of sex on judging. American Journal of Political Science, v. 54, n. 2, p. 389-411, 2010.; KENNEY, Sally J. Thinking about gender and judging. International Journal of the Legal Profession, v. 15, n. 1-2, p. 87-110, mar./jul. 2008.

134 O inteiro teor da decisão (Burwell v. Hobby Lobby, 573 U.S, 2014) está disponível em: <http://www.supremecourt.gov/ opinions/13pdf/13-354_olp1.pdf>. Acesso em: 29 maio 2018.

135 FLATOW, Nicole. Ruth Bader Ginsburg: male justices don't understand what hobby lobby meant for women. Think Progress, jul. 2014. Disponível em: <thinkprogress.org/justice/2014/07/31/3466213/ruth-bader-ginsburg-male-justices-dont- understandwhat-hobby-lobby-meant-for-women>. Acesso em: 29 maio 2018. 
na sobre os julgamentos. Além disso, apesar de o resultado ter sido desfavorável às mulheres, a apresentação de votos divergentes pelas juízas cumpre um papel democrático ao pluralizar os pontos de vista e enriquecer o debate público com o acréscimo de perspectivas.

Essa tese está sintonizada com a ideia de que a representação serve como um canal de compartilhamento de perspectivas sociais. Iris Marion Young, desenvolvendo as formulações de Hanna Pitkin, sustenta que a representação pode ser calcada em opiniões, interesses e perspectivas. Segundo a autora, a "diferenciação de grupos propicia recursos para um público democrático comunicativo que visa estabelecer a justiça, uma vez que pessoas diferentemente posicionadas têm diferentes experiências, histórias e compreensões sociais, derivadas daquele posicionamento" ${ }^{136}$. Isso significa que, conforme a posição que ocupam na sociedade, as pessoas elaboram significados e se engajam em certas formas de relacionamentos sociais distintos, com os quais pessoas de grupos diferentes não se associam, sendo que, em certos cenários, sequer terão consciência de como operam. Em geral, a inserção em determinado grupo social confere às pessoas entendimentos distintos dos fatos sociais e de seus desdobramentos. Portanto, "cada grupo diferentemente posicionado tem uma experiência ou um ponto de vista particular acerca dos processos sociais precisamente porque cada qual faz parte desses processos e contribui para produzir suas configurações". Para Young, "é especialmente quando estão situadas em diferentes lados das relações de desigualdade estrutural que as pessoas entendem essas relações e suas consequências de modos diferentes"137.

Nesse contexto, para que o judiciário atenda ao ideal regulativo de ser apto a atuar na condição de representante da sociedade no debate jurídico, as cortes devem espelhar a pluralidade da sociedade.

\section{ENCERRAMENTO}

A expansão da esfera de ação do poder judiciário é um fenômeno presente na maior parte das democracias ocidentais contemporâneas.

No cenário brasileiro, os tribunais converteram-se em protagonistas incontornáveis nos debates políticos. Na última década, os ministros do Supremo passaram a falar abertamente na corte como "uma casa de fazer destino"138, a imputar aos juízes a função de "representantes argumentativos" 139 da sociedade e a entender que podem agir como intérpretes do "sentimento social"140.

Os julgamentos televisionados transformaram-se em espetáculos ${ }^{141}$ fascinantes que ora se apresentam como reações aos movimentos sociais, ora operam como ações que deflagram combustões políticas.

Essa centralidade no judiciário na dinâmica estatal e social - ainda que preocupante e criticável por ser qualificada como causa ou talvez como sintoma da disfuncionalidade das instâncias tradicionais de representação - coloca em evidência que as fronteiras que separam direto e política, que jamais foram claras, estão cada vez mais borradas.

Uma vez que os juízes são percebidos como atores relevantes na dinâmica da construção do significado do direito e das políticas públicas, torna-se natural aplicar à sua composição a premissa essencial do ideal democrático, segundo a qual aqueles que são afetados pelas decisões do estado devem estar aptos a acessar

136 YOUNG, Iris Marion. Representação política, identidade e minorias. Lua Nova, São Paulo, n. 67, p. 139-190, 2006.

137 YOUNG, Iris Marion. Representação política, identidade e minorias. Lua Nova, São Paulo, n. 67, p. 162, 2006.

138 Foi o que afirmou o Ministro Carlos Britto em seu voto durante o julgamento da ADI 3510-0.

139 Foi o que afirmou o Ministro Gilmar Mendes em seu voto durante o julgamento da ADI 3510- 0.

140 ROXO, Sérgio. Barroso diz que Constituição deve ser interpretada em 'sintonia com o sentimento social'. O Globo, abr. 2018. Disponível em: <https://oglobo.globo.com/brasil/barroso-diz-que-constituicao-deve-ser-interpretada-em- sintonia-comsentimento-social-22549589>. Acesso em: 31 maio 2018.

141 MELLO, Patrícia Perrone Campos. Quando julgar se torna um espetáculo: a interação entre o Supremo Tribunal Federal e a opinião pública, a partir de reflexões da literatura estrangeira. Revista de Direito Internacional, Brasília, v. 14, n. 1, p. $402-423,2017$. 
os órgãos que as formulam. Conforme aumenta o poder dos juízes de interferir no rumo da vida social, cresce em importância a discussão sobre quem integra os tribunais, que critérios de acesso são empregados e de que forma se deve buscar que os vários grupos sociais estejam neles representados.

Não se trata de adotar uma leitura essencialista, segundo a qual as mulheres teriam atributos particulares que representariam um ganho de resultado na performance ou na qualidade da decisão das cortes. A questão crucial no debate sobre a carência de diversidade nos tribunais repousa no ganho de legitimidade que advém do fato de serem compostos por pessoas de perspectivas diferentes, bem como na ativação da dimensão simbólica da democracia. Essa leitura não é incompatível com o ideal de que os juízes atuem com imparcialidade, precisamente porque não se presume que os julgamentos serão diferentes pelo fato de serem conduzidos por homens ou mulheres. Trata-se de reconhecer que, no plano simbólico, a confiança nas decisões depende não apenas dos resultados que produzem, mas da percepção de que são institucionalmente acessíveis àqueles que são destinatários de suas ordens. Um judiciário que encerra equilíbrio de gênero expressa em sua textura institucional uma mensagem de equivalência de status cívico entre homens e mulheres. Isso porque, afinal, o pessoal é político, e o judiciário também.

\section{REFERÊNCIAS}

A TRAJETÓRIA da primeira mulher a integrar o Supremo. Consultor Jurídico, São Paulo, ago. 2011. Disponível em: <https://www.conjur.com.br/2011-ago-11/ellen-gracie-trajetoria-primeira-mulher-integrarsupremo>. Acesso em: 29 maio 2018.

ABRAHAMSON, Shirley S. The woman has robes: four questions. Golden Gate Law Review, v. 14, n. 3, p. 489-503, 1984.

ALEGRETTI, Laís. Plenário do Senado terá banbeiro feminino 55 anos após inauguração. Brasília. 2016. Disponível em: <http://g1.globo.com/politica/noticia/2016/01/plenario-do-senado-tera-banheiro-feminino-55-anos-apos-inauguracao.html>. Acesso em: 27 maio 2018.

ALEXY, Robert. Balancing, constitutional review and representation. International Journal of Constitutional Law, v. 3, n. 4, p. 572-581, out. 2005.

ALMEIDA, Maria Cândida. Mulheres, vieses implícitos e o judiciário. Jota, mar. 2018. Disponível em: $<$ https://www.jota.info/opiniao-e-analise/artigos/mulheres-vieses-implicitos-e-o-judiciario-12032018>. Acesso em: 29 maio 2018.

ALMEIDA, Rodolfo; ZANLORENSSI, Gabriel. Gênero e raça de estudantes do ensino superior no Brasil por curso e área. Nexo Jornal, dez. 2017. Disponível em: <https://www.nexojornal.com.br/grafico/2017/12/13/Gênero-e-raça-de-estudantes-do-ensino-superior-no-Brasil-por-curso-e-área>. Acesso em: 29 maio 2018.

ALVES, Clara da Mota Santos Pimenta. Gênero, espaço público e poder: uma análise sobre a composição das comissões examinadoras de concurso da magistratura. Revista Publicum, Rio de Janeiro, v. 3, n. 1, p. 352$370,2017$.

AMOSSY, Ruth (Org.). Imagens de si no discurso: a construção do ethos. São Paulo: Contexto, 2005.

ARAUJO, Heloisa Bianquini. Qual o gênero do Supremo?: diálogo institucional nas sabatinas para o STF, poder e profissionalismo. 2015. Trabalho de Conclusão de Curso (Graduação em Direito) - Escola de Formação da Sociedade Brasileira de Direito Público, São Paulo, 2015.

BANAJI, M.; GREENWALD, A. Blindspot: hidden biases of good people. New York: Delacorte Press, 2013.

BARROSO, Luís Roberto. Contramajoritário, representativo e iluminista: os papeis dos tribunais constitu- 
cionais nas democracias contemporâneas. Direito \& Práxis, Rio de Janeiro, 2017.

BARROSO, Luís Roberto; MENDONÇA, Eduardo. A razão sem voto: o Supremo Tribunal Federal e o governo da maioria. Revista Brasileira de Políticas Públicas, v. 5, p. 23-50, 2015.

BARROSO, Luís Roberto; MENDONÇA, Eduardo. Retrospectiva 2012: STF entre seus papéis contramajoritário e representativo. 2012. Disponível em: <http://www.conjur.com.br/2013-jan-03/retrospectiva2012-stf-entre-papeis-contramajoritario-representativo>. Acesso em: 27 maio 2018.

BASILE, Juliano. Para presidente do STF, tribunal supre deficiências do Legislativo. Valor Econômico, São Paulo, jun. 2008. Disponível em: < http://www.valoronline.com.br/valoreconomico/285/primeirocaderno/politica/Para + o+ presidente + do + STF + tribunal+supre+deficiencias + do +Legislativo, ,60,4973950.htm l?highlight $=$ \&newsid $=4973950$ \&areaid=60\&editionid=2023 $>$. Acesso em: 27 maio 2018.

BENHABIB, Seyla. Situating the self: gender, community and postmodernity in contemporary ethics. Cambridge: Polity, 1992.

BERNADETE Pedrosa, a primeira mulher a ser admitida como professora da Faculdade de Direito do Recife em 1965. 2018. Disponível em: <https://www.ufpe.br/arquivoccj/curiosidades/-/asset_publisher/ x1R6vFfGRYss/content/1965-primeira-professora-de-direito-no-recife/590249>. Acesso em: 29 maio 2018.

BERNS, Sandra. To speak as a judge: difference, voice and power. Dartmouth: Ashgate, 1999.

BOBBIO, Norberto. O positivismo jurídico: lições de filosofia do direito. São Paulo: Ícone, 1995.

BÖCKENFÖRDE, Ernst-Wolfgang. Democracia y representación: crítica a la discusión actual sobre la democracia. In: BÖCKENFÖRDE, Ernst-Wolfgang. Estudios sobre el Estado de Derecho y la democracia. Madrid: Trotta, 1993.

BOHNET, Iris. What works: gender equality by design. London: Harvard University Press, 2016.

BOLTON, Sharon C.; MUZIO, Daniel. Can't live with 'Em; Can't Live without 'Em: gendered segmentation in the legal profession. Sociology, Chicago, v. 41, n. 1, p. 47-64, 2007.

BONELLI, Maria da Glória. Profissionalismo e diferença de gênero na magistratura paulista. Civitas, Porto Alegre, v. 10, n. 2, p. 270-292, maio/ago. 2010.

BONELLI, Maria da Glória. Profissionalismo, gênero e significados da diferença entre juízes e juízas estaduais e federais. Contemporânea, n. 1, p. 103-123, jan./jun. 2011.

BOURDIEU, Pierre. Distinction: a social critique of the judgment of taste. Cambridge: Harvard University Press, 1984 [1979].

BOURDIEU, Pierre. Esboço de uma teoria da prática: precedido de três estudos de etnologia kabila. Oeiras: Celta, 2002 [1972].

BOURDIEU, Pierre. The logic of practice. Cambridge: Polity Press, 1990 [1980].

BOYD, Christina L.; EPSTEIN, Lee; MARTIN, Andrew D. Untangling the causal effects of sex on judging. American Journal of Political Science, v. 54, n. 2, p. 389-411, 2010.

BRAH, Avtar. Diferença, diversidade e diferenciação. Cardenos Pagu, Campinas, v. 26, p. 329-376, jan./jun. 2006.

BRASIL. Conselho Nacional de Justiça. Censo do Poder Judiciário: VIDE: Vetores iniciais e dados estatísticos. Brasília: CNJ, 2014.

CAMARGO, Margarida Maria Lacombe. Interpretação constitucional. In: CAMARGO, Margarida Maria Lacombe (Org.). 1988-1998: uma década de constituição. Rio de Janeiro: Renovar, 1999. 
CAMERER, Colin F.; LOEWENSTEIN, George; RABIN, Matthew (Eds.). Advances in behavioral economics. Princeton: Princeton University Press, 2004.

CECCHI-DIMEGLIO, P. How gender Bias corrupts performance reviews, and what to do about it. Harvard Business Review, apr. 2017. Disponível em: < https://hbr.org/2017/04/how-gender-bias-corrupts-performance-reviews-and-what-to-do-about-it>. Acesso em: 29 maio 2018.

COLBY, Anne; DAMON, William. Listening to a different voice: a review of Gilligan's "in a different voice". Merrill-Palmer Quarterly, v. 29, n. 4, p. 473-481, oct. 1983.

COMISSÃO AJUFE MULHERES. Nota Técnica: AJUFE mulheres 01/2017: resultados da pesquisa para se conhecer o perfil das associadas da AJUFE. Brasília: AJUFE Mulheres, 2017.

CONAGHAN, J. Reassessing the Feminist Theoretical Project in law. Journal of Law \& Society, v. 27, n. 3, p. 351-385, 2000.

CONHEÇA a primeira mulher a ocupar o cargo de juíza no país. Donna, out. 2008. Disponível em: < http:// revistadonna.clicrbs.com.br/noticia/conheca-a-primeira-mulher-a-ocupar-o-cargo-de-juiza-no-pais/>. Acesso em: 29 maio 2018.

CORBO, Wallace. Discriminação indireta: conceito, fundamentos e uma proposta de enfrentamento à luz da Constituição de 1988. Rio de Janeiro: Lumen Juris, 2017.

CRENSHAW, Kimberlé Williams; CHO, Sumi; MCCALL, Lesli. Demarginalizing the intersection of race and sex: a black feminist critique of antidiscrimination doctrine, feminist theory and antiracist politics. The University of Chicago Legal Forum, v. 139, p. 139-167, 1989.

CRENSHAW, Kimberlé Williams; CHO, Sumi; MCCALL, Lesli. Mapping the margins: intersectionality, identity politics, and violence against women of color. Stanford Law Review, v. 43, n. 6, p. 1241-1299, 1991.

CRENSHAW, Kimberlé Williams; CHO, Sumi; MCCALL, Lesli. Toward a field of intersectionality studies: theory, applications, and praxis. Signs: Journal of Women in Culture and Society, v. 38, n. 4, p. 785-810, 2013.

CRUZ, Adriana Alves dos Santos; ALVIM, Alcione Escobar da Costa. As questões raciais e poder judiciário: enfrentamentos necessários. In: PIMENTA, Clara Mota et al (Orgs.). Magistratura e equidade: estudos sobre gênero e raça no poder judiciário. Belo Horizonte: D’Plácido, 2018.

DANNENBAUM, Tom. Nationality and the international judge: the nationalist presumption governing the international judiciary and why it must be reversed. Cornell International Law Journal, v. 45, p. 77-184, 2012.

DAVIDSON, M. J.; COOPER, C. L. Shattering the glass ceiling: the woman manager. London: Paul Chapman Publishing, 1992.

DAVIS, Angela. Mulheres, raça e classe. São Paulo: Boitempo, 2016.

D’ELLA, Mirella. Ministra quebra tradição e usa calça no STF. Brasília. 2007. Disponível em: <http://g1.globo. com/Noticias/Politica/0,MUL11565-5601,00-MINISTRA+QUEBRA+TRADICAO+E+USA+CALCA +NO+STF.html>. Acesso em: 27 maio 2018.

DUARTE, Cláudia Türner Pereira. O sistema familiar na teoria política: repensando o lugar da criança na teoria da justiça. 2016. Dissertação (Mestrado em Direito) - Universidade do Estado do Rio de Janeiro, Rio de Janeiro, 2016.

DWORKIN, Ronald. O império do direito. São Paulo: Martins Fontes, 1999.

EISGRUBER, Christopher L. Constitutional self-government. Cambridge: Harvard University Press, 2001.

FEENAN, Dermot. Editorial introduction: women and judging. Feminist Legal Studies, v. 17, p. 1-9, 2009.

FLATOW, Nicole. Ruth Bader Ginsburg: male justices don't understand what hobby lobby meant for wo- 
men. Think Progress, jul. 2014. Disponível em: <thinkprogress.org/justice/2014/07/31/3466213/ruth-bader-ginsburg-male-justices-dont-understand-what-hobby-lobby-meant-for-women>. Acesso em: 29 maio 2018 .

FRAGALE FILHO, Roberto; MOREIRA, Rafaela Selem; SCIAMMARELLA, Ana Paula de O. Magistratura e gênero: um olhar sobre as mulheres nas cúpulas do judiciário brasileiro. E-cadernos CES, n. 24, p. 57-77, 2015.

FRANK, Jerome. The cult of the robe. In: FRANK, Jerome. Courts on trial: myth and reality in american justice. Princeton: Princeton University Press, 1973.

GILLIGAN, Carol. In a different voice: psychological theory and women's development. Cambridge: Harvard University Press, 2003.

GREENO, Catherine G.; MACCOBY, Eleanor E. How different is the "different voice"?. Signs, v. 11, n. 2, p. 310-316, 1986.

GUEDES, Moema de Castro. A presença feminina nos cursos universitários e nas pós-graduações: desconstruindo a idéia da universidade como espaço masculino. História, Ciências, Saúde - Manguinhos, Rio de Janeiro, v. 15 , p. $117-132$, jun. 2008.

GUIMARÃES, Lúcia Maria Paschoal; FERREIRA, Tania Maria Tavares. Myrthes Gomes de Campos (1875?): pioneirismo na luta pelo exercício da advocacia e defesa da emancipação feminina. Revista do Instituto de Estudos de Gênero, Niterói, v. 9, n. 2, p. 135-151, 2009.

GVOZDANOVIC, J. Implicit bias in academia: a challenge to the meritocratic principle and to women's career - and what to do about it. League of European Research Universities, n. 23, 2018.

HALE, Brenda. Lady Hale gives the Fiona woolf lecture for the women lawyers' division of the Law Society: women in the Judiciary. 2014. Disponível em: <https://www.supremecourt.uk/docs/speech-140627.pdf>. Acesso em: 27 maio 2018.

HANISCH, Carol. The personal is political. Disponível em: < http://www.carolhanisch.org/CHwritings/PIP. html>. Acesso em: 30 maio 2018.

HARVEY, John. Homens de preto. São Paulo: Unesp, 1995.

HEIDENSOHN, Frances (Ed.). Gender and justice: new concepts and approaches. Portland: Willan Publishing, 2006.

HIRATA, Helena. Gênero, classe e raça: interseccionalidade e consubstancialidade das relações sociais. Tempo Social, São Paulo, v. 26, n. 1, p. 61-73, 2014.

HOOKS, Bell. Ain't i a woman: black women and feminism. Boston: South End Press, 1981.

HOOKS, Bell. Feminism is for everybody: passionate politics. London: Pluto Press, 2000.

HOOKS, Bell. Teaching to transgress: education as the practice of Freedom. New York: Routledge, 1994.

HUNTER, Rosemary C.; SHOBEN, Elaine W. Disparate impact discrimination: american oddity or internationally accepted concept? Berkley Journal of Employment and Labor Law, v. 19, n. 1, p. 108-152, 1998.

INSTITUTO NACIONAL DE ESTUDOS E PESQUISAS EDUCACIONAIS. Censo da Educação Superior 2015: resumo técnico. Brasília: INEP, 2018.

INTITUTO BRASILEITO DE GEOGRAFIA E ESTATÍSTICA. Estatísticas de gênero: indicadores sociais das mulheres no Brasil. Estudos e Pesquisas - Informação Demográfica e Socioeconômica, n. 38, 2018.

ISAULA, Rodolfo. Toga de jueces, um luto de siglos. El Heraldo, abr. 2014. Disponível em: <http://www. elheraldo.hn/alfrente/566256-209/toga-de-jueces-un-luto-de-siglos>. Acesso em: 31 maio 2018. 
ITO, Marina; SCRIBONI, Marília. Em pouco tempo, mulheres estarão na cúpula da Justiça. Consultor Jurídico, mar. 2012. Disponível em: <https://www.conjur.com.br/2012-mar-08/aumenta-numero-mulheres-direitosao-chegam-cupula>. Acesso em: 28 maio 2018.

KAHNEMAN, Daniel; TVERSKY, Amos. The simulation heuristic. In: KAHNEMAN, Daniel; TVERSKY, Amos; SLOVIC, P. (Org.). Judgment under uncertainty: heuristics and biases. New York: Cambridge University Press, 1982.

KAHNEMAN, Daniel; TVERSKY, Amos. Thinking, fast and slow. New York: Farrar Straus Giroux, 2013.

KENNEDY, Walter B. The cult of the robe: a dissent. Fordham Law Review, v. 14, n. 2, p. 192-196, 1945.

KENNEY, Sally J. Gender \& justice: why women in the judiciary really matter. New York: Routledge, 2012.

KENNEY, Sally J. Thinking about gender and judging. International Journal of the Legal Profession, v. 15, n. 1-2, p. 87-110, mar./jul. 2008.

LEE, Connie. Gender Bias in the Courtroom: combating implicit Bias against women trial attorneys and litigators. Cardozo Journal of Law \& Gender, v. 22, n. 229, p. 229-252, 2016.

MALLESON, Kate. Justifying gender equality on the bench: why difference won't do. Feminist Legal Studies, v. 11, p. 1-24, 2003.

MELLO, Patrícia Perrone Campos. Nos bastidores do Supremo Tribunal Federal: Constituição, emoção, estratégia e espetáculo. São Paulo: GEN, 2015.

MELLO, Patrícia Perrone Campos. Quando julgar se torna um espetáculo: a interação entre o Supremo Tribunal Federal e a opinião pública, a partir de reflexões da literatura estrangeira. Revista de Direito Internacional, Brasília, v. 14, n. 1, p. 402-423, 2017.

MELO, Hildete Pereira de; THOMÉ, Débora. Mulheres e poder: histórias, ideias e indicadores. Rio de Janeiro: FGV, 2018.

MELO, Mônica de; NASTARI, Marcelo; MASSULA, Letícia. A participação da mulher na magistratura brasileira. Disponível em: <http://www.spm.gov.br/assuntos/poder-e-participacao-politica/programas-acoes/ desigualdades-entre-mulheres-e-homens/judiciario/dados_parciais_de_1999_a_20.pdf?TSPD_101_R0=5 8c632ceeac2b962cdb498af875432cdoB200000000000000000c279eb1 ffff000000000000000000000000000 05b11ef5d001b0182d8>. Acesso em: 28 maio 2018.

MENKEL-MEADOW, Carrie. Portia in a different voice: speculations on a women's lawyering process. Berkley Journal of Gender, Law \& Justice, v. 1, n. 1, p. 39-63, 1985.

MILL, John Stuart. The subjection of women. Indianapolis: Hackett Publishing Company, 1988.

MOORE, Dorothy Perrin; BUTTNER, E. Holly. Women entrepreneurs: moving beyond the glass ceiling. Thousand Oaks: SAGE Publications, 1997.

MORRE primeira mulher a ocupar cargo de ministra no TST. Consultor Jurídico, abr. 2008. Disponível em: $<$ https://www.conjur.com.br/2008-abr-23/morre_primeira_mulher_ocupar_cargo_ministra_tst $>$. Acesso em: 28 maio 2018.

MORRISON, Ann M.; WHITE, Randall P.; VELSOR, Ellen Van. Breaking the glass ceiling: can women reach the top of America's largest corporations?. 2. ed. Beverly: Basic Books, 1994.

MOTTA, Francisco J. Borges. Levando o direito a sério: uma crítica hermenêutica ao protagonismo judicial. Florianópolis: Conceito, 2010.

MULHERES são maioria em universidades e cursos de qualificação. 2016. Disponível em: <http://www. brasil.gov.br/economia-e-emprego/2016/03/mulheres-sao-maioria-em-universidades-e-cursos-de-qualifi- 
cacao?TSPD_101_R0=146a5e670db17b1d43690f8f65521871n6o00000000000000000c279eb1ffff0000000 $0000000000000000000005 b 117 b b 600$ ea8281fc>. Acesso em: 29 maio 2018.

MULHERES são maioria no ingresso e na conclusão de cursos superiores. 2017. Disponível em: < http:// www.brasil.gov.br/editoria/educacao-e-ciencia/2015/03/mulheres-sao-maioria-no-ingresso-e-na-conclusao-de-cursos-superiores?TSPD_101_R0=dee602bb551a76a45283dee5ab5e0d4cc1Q00000000000000000 c279eb1ffff00000000000000000000000000005b11770d0076024db4>. Acesso em: 29 maio 2018.

NEGOWETTT, N. E. Implicit Bias and the legal profession's 'diversity crisis': a call for self-reflection. Nevada Law Journal, Las Vegas, v. 15, p. 431-460, 2015.

NONATO, Israel. O Supremo não éoráculo: conversas acadêmicas com Jane Reis. 2013. Disponível em: < http:/ / www.osconstitucionalistas.com.br/jane-reis-o-supremo-nao-e-oraculo>. Acesso em: 29 maio 2018.

NUSSBAUM, Martha C. Sex \& social justice. Oxford: Oxford University Press, 1999.

OKIN, Susan Moller. Gênero, o público e o privado. Estudos feministas, Florianópolis, v. 16, n. 2, p. 305-332, maio/ago. 2008.

OKIN, Susan Moller. Justice, gender and the family. New York: Basic Books, 1989.

OLIVEIRA, Rafael Tomaz de. Decisão judicial e o conceito de princípio: a hermenêutica e a (in)determinação do direito. Porto Alegre: Livraria do Advogado, 2008.

OST, François. Júpiter, Hércules, Hermes: tres modelos de juez. Doxa: Cuadernos de Filosofía del Derecho, n. 14, p. 169-194, 1993.

PATEMAN, Carole. The sexual contract. Stanford: Stanford University Press, 1988.

PEREIRA, Jane Reis Gonçalves. Representação democrática do Judiciário: reflexões preliminares sobre os riscos e dilemas de uma ideia em ascensão. Juris Poiesis, Rio de Janeiro, v. 17, p. 343-359, 2014.

PEREIRA, Jane Reis Gonçalves. Retrospectiva Direito Constitucional 2008: a expansão do Judiciário e o constitucionalismo cosmopolita. Revista Direito do Estado, v. 13, p. 23-53, 2008.

PHILLIPS, Anne. The politics of presence. Oxford: Oxford University Press, 1995.

PITKIN, Hannah Fenichel. The concept of representation. Berkeley: University of California Press, 1967.

PODER Legislativo: porcentagem de mulheres no órgão legislativo nacional: Câmara baixa ou única. 2018. Disponível em: < https://oig.cepal.org/pt/indicadores/poder-legislativo-porcentagem-mulheres-no-orgaolegislativo-nacional-camara-baixa-ou>. Acesso em: 30 maio 2018.

POGREBINSCHI, Thamy. Judicialização ou representação: política, direito e democracia no Brasil. Rio de Janeiro: Elsevier, 2011.

RACKLEY, Erika. Representations of the (woman) judge: Hercules, the little mermaid, and the vain and naked Emperor. Legal Studies, v. 22, n. 4, p. 602-624, nov. 2002.

RACKLEY, Erika. Women, judging and the Judiciary: from difference to diversity. New York: Routledge, 2013. RAWLS, John. A theory of justice. Cambridge: Harvard University Press, 2003.

ROXO, Sérgio. Barroso diz que Constituição deve ser interpretada em 'sintonia com o sentimento social'. O Globo, abr. 2018. Disponível em: <https://oglobo.globo.com/brasil/barroso-diz-que-constituicao-deveser-interpretada-em-sintonia-com-sentimento-social-22549589>. Acesso em: 31 maio 2018.

SALDANHA, Nelson. O jardim e a praça: ensaio sobre o lado privado e o lado público da vida social e histórica. Porto Alegre: Sergio Antonio Fabris Editor, 1986.

SCHULTZ, Ulrike; SHAW, Gisela (Ed.). Gender and judging. Oxford: Hart Publishing, 2013. 
SCOTT, Joan. Gênero: uma categoria útil de análise histórica. Educação \& Realidade, Porto Alegre, v. 20, n. 2, p. 71-99, jul./dez. 1995.

SENCHUK, D. M. Listening to a different voice: a feminist critique of Gilligan. Studies in Philosopby and Education, v. 10, n. 3, p. 233-249, 1990.

SONGER, Donald R. The transformation of the Supreme Court of Canada: an empirical examination. Toronto: University of Toronto Press, 2008.

STRECK, Lenio. O pós-positivismo e os propalados modelos de juiz (Hércules, Júpiter e Hermes) - dois decálogos necessários. Revista de Direitos e Garantias Fundamentais, v. 7, p. 15-45, 2011.

SUNSTEIN, Cass R. Why nudge: the politics of libertarian paternalism. New Haven: Yale University Press, 2014.

THALER, Richard H. Mishehaving: the making of behavioral economics. New York: W. W. Norton \& Company, 2016.

THALER, Richard H.; SUNSTEIN, Cass R. Nudge: improving decisions about health, wealth, and happiness. New Haven: Yale University Press, 2008.

TIERNEY, Stephen. We the peoples: constituent power and constitutionalism in plurinational states. In: WALKER, Neil; LOUGHLIN, Loughlin (Org.). The paradox of Constitutionalism. Oxford: Oxford University Press, 2007. p. 229-246.

TVERSKY, Amos; KAHNEMAN, Daniel. The framing of decisions and the psychology of choice. Science, v. 211, p. 453-458, 1981.

UNITED NATIONS. The world's women 2015. 2015. Disponível em: < https:/ unstats.un.org/unsd/gender/ chapter4/chapter4.html>. Acesso em: 10 maio 2018.

UNITED NATIONS. Women in politics: 2017. 2017. Disponível em: <https://www.ipu.org/resources/publications/infographics/2017-03/women-in-politics-2017>. Acesso em: 30 maio 2018.

WACQUANT, Loïc. Esclarecer o habitus. Educação \& Linguagem, ano 10, n. 16, p. 63-71, jul./dez. 2007.

WALKER, Peter. Don't rush gender equality in UK judiciary, says supreme court judge. The Guardian, sep. 2015. Disponível em: < https://www.theguardian.com/law/2015/sep/22/gender-equality-warning-uklegal-profession-supreme-court-judge-jonathan-sumption>. Acesso em: 31 maio 2018.

WILLBORN, Steven L. The disparate model of discrimination: theory and limits. American University Law Review, v. 34, p. 799-839, 1985.

WILSON, Bertha. Will women judges really make a difference? Osgoode Hall Law Journal, v. 28, n. 3, p. 507$522,1990$.

WITT, Charlotte (Coord.). Feminist metaphysics: explorations in the ontology of sex, gender and the self. Londres: Springer, 2011.

YOUNG, Iris Marion. Representação política, identidade e minorias. Lua Nova, São Paulo, n. 67, p. 139-190, 2006.

Agradecimentos

Agradecemos à Adriana Cruz, ao Gabriel Accioly Gonçalves e ao Leandro Carlos Dias Conde pelos debates e pela revisão deste artigo, bem como à Comissão AJUFE Mulheres, na pessoa de Clara Mota Alves, pelo compartilhamento de dados. 
Para publicar na revista Brasileira de Políticas Públicas, acesse o endereço eletrônico www.rbpp.uniceub.br

Observe as normas de publicação, para facilitar e agilizar o trabalho de edição. 